\title{
Application of a Modified Low-Field NMR Method on Methane Adsorption of Medium-Rank Coals
}

\author{
Xiaozhen Chen, ${ }^{1,2}$ Taotao Yan $\mathbb{D}^{1,2,3}$ Fangui Zeng $\mathbb{D}^{1,2}$ Yanjun Meng, ${ }^{1,2}$ and Jinhua Liu ${ }^{3}$ \\ ${ }^{1}$ Department of Earth Science and Engineering, Taiyuan University of Technology, Taiyuan, 030024 Shanxi, China \\ ${ }^{2}$ Shanxi Key Laboratory for Geology and Exploration of Coal and Coal Measure Gas, China \\ ${ }^{3}$ Beijing Key Laboratory of Unconventional Natural Gas Geological Evaluation and Development Engineering, China University \\ of Geosciences, Beijing 100083, China
}

Correspondence should be addressed to Taotao Yan; taotao87225@163.com and Fangui Zeng; zengfangui@tyut.edu.cn

Received 25 December 2020; Revised 28 January 2021; Accepted 8 February 2021; Published 5 March 2021

Academic Editor: Yingfang Zhou

Copyright (C) 2021 Xiaozhen Chen et al. This is an open access article distributed under the Creative Commons Attribution License, which permits unrestricted use, distribution, and reproduction in any medium, provided the original work is properly cited.

\begin{abstract}
Methane adsorption capacity is an important parameter for coalbed methane (CBM) exploitation and development. Traditional examination methods are mostly time-consuming and could not detect the dynamic processes of adsorption. In this study, a modified low-field nuclear magnetic resonance (NMR) method that compensates for these shortcomings was used to quantitatively examine the methane adsorption capacity of seven medium-rank coals. Based on the typical $T_{2}$ amplitudes obtained from low-field NMR measurement, the volume of adsorbed methane was calculated. The results indicate that the Langmuir volume of seven samples is in a range of $18.9-31.85 \mathrm{~m}^{3} / \mathrm{t}$ which increases as the coal rank increases. The pore size in range $1-10 \mathrm{~nm}$ is the main contributor for gas adsorption in these medium-rank coal samples. Comparing the adsorption isotherms of these coal samples from the modified low-field NMR method and volumetric method, the absolute deviations between these two methods are less than $1.03 \mathrm{~m}^{3} / \mathrm{t}$ while the relative deviations fall within $4.76 \%$. The absolute deviations and relative deviations decrease as vitrinite reflectance $\left(R_{\mathrm{o}}\right)$ increases from $1.08 \%$ to $1.80 \%$. These results show that the modified low-field NMR method is credible to measure the methane adsorption capacity and the precision of this method may be influenced by coal rank.
\end{abstract}

\section{Introduction}

The gas adsorption property in a coal seam was controlled by its physical and chemical structure $[1,2]$. Therefore, the adsorption characteristic of gas in a coal seam is comparatively complex in comparison to that in traditional reservoirs. Previous researches about adsorption mainly focus on theory and model of methane adsorption [3-6], controlling factors of the gas adsorption process [7-16], and competitive adsorption mechanism [17-22]. Generally, coalbed methane is mainly stored as an adsorbed phase in the micropores, and a few parts are stored as a free phase in macropores and fractures. Thus, the measurement of adsorbed methane in a reservoir is critical for choosing a favorable exploration area and designing engineering parameters during production processes.
Methane adsorption property in coal is usually determined according to the (a) volumetric method [23-29], (b) gravimetric method [30-32], or (c) manometric method [33-35]. These methods could not continuously detect the dynamic process of adsorption and are always timeconsuming. Thus, researchers tried to obtain the adsorption property by other methods.

As an instantaneous, in situ, and dynamic method, the low-field NMR method has been used in the field of unconventional reservoir characterization (i.e., permeability, porosity, and wettability) in recent years [36-47]. There are, however, quite few studies involving low-field NMR relaxation characteristics of adsorbed methane in coal. Guo et al. [48] used a low-field NMR amplitude index from bulk methane to quantify the mass and volume of adsorbed methane in 


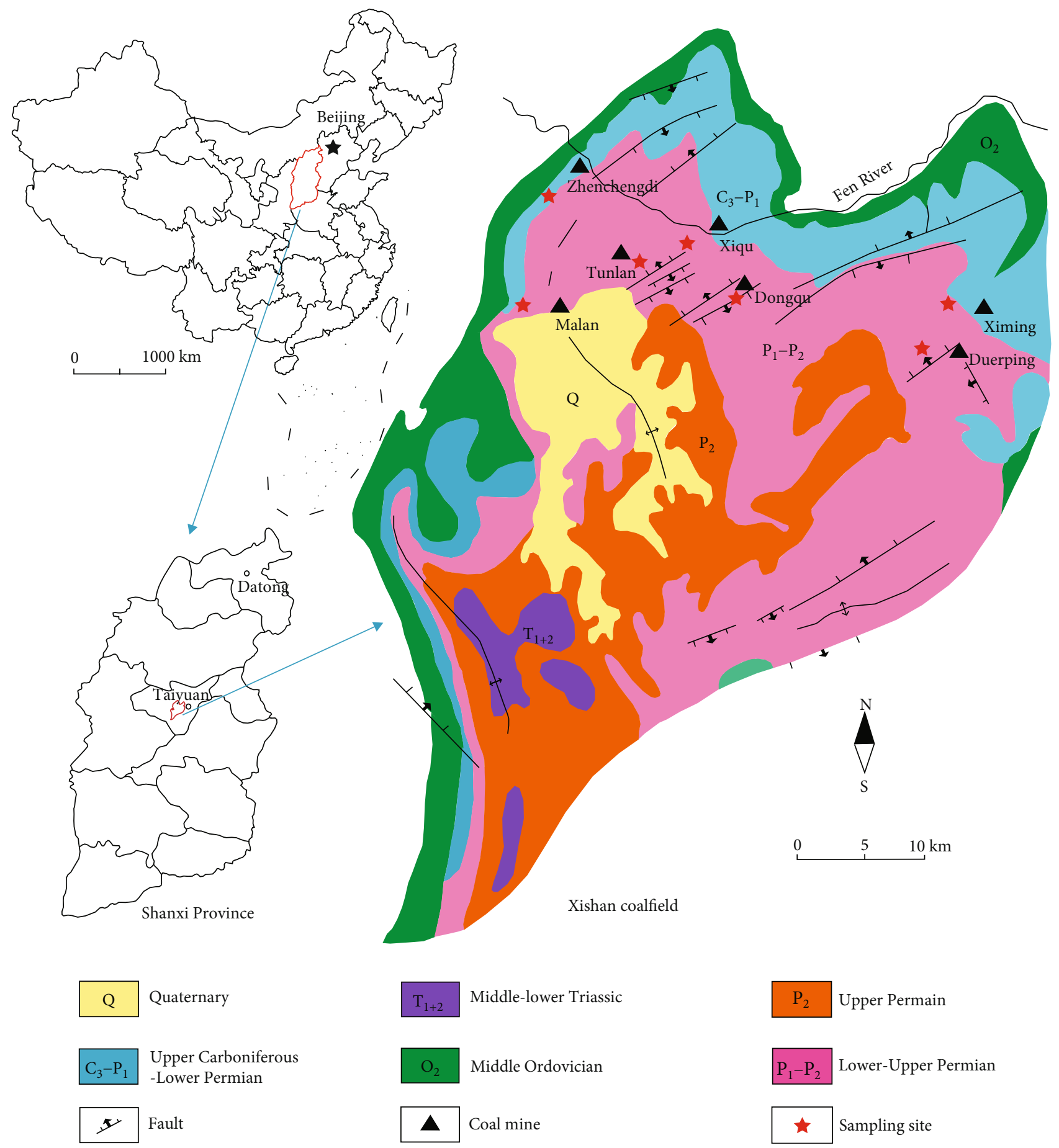

FIGURE 1: Xishan structural outline map and sample collection location.

two low volatile bituminous coals, without distinguishing the bulk methane and adsorbed methane relaxation properties. Yao et al. [49] and Xie [43] built an NMR transparent isotherm adsorption experimental setup to evaluate the capacity of methane in coal. The deviations between their method and traditional volumetric method are in range of $0.50 \%-11.09 \%$. Then, Yao et al. [50] improved the low-field NMR method by taking a factor "pipeline volume" into consideration and applied it to calculate the adsorbed methane volume in two shale samples. The calculated adsorbed methane volumes fit well with values from the gravimetric method. As an organic rock, the pore property (i.e., types, structure, and pore size distribution) of coal is different to that of shale rock which would influence the gas adsorption performance in reservoirs. However, to the best of the authors' knowledge, the suitability of this modified low-field NMR method [50] on a coal sample and the influence of the coal rank on the results from this method have never been discussed. In this study, 


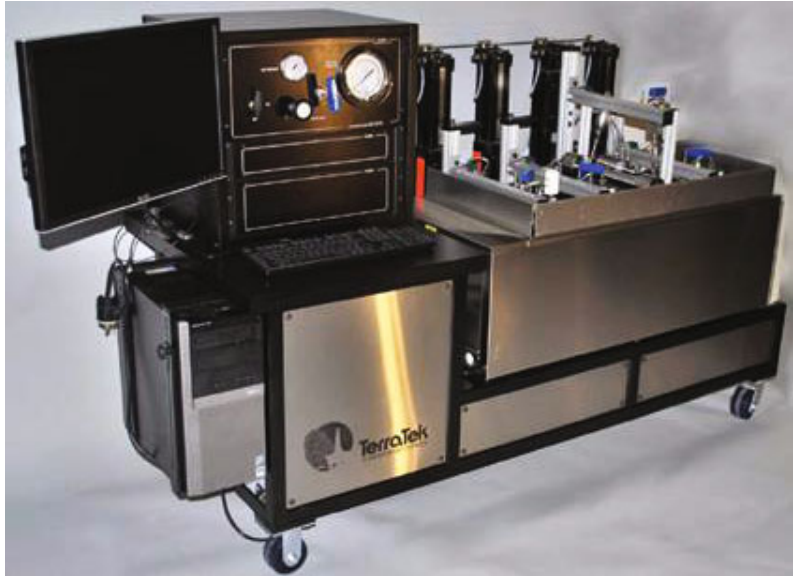

(a)

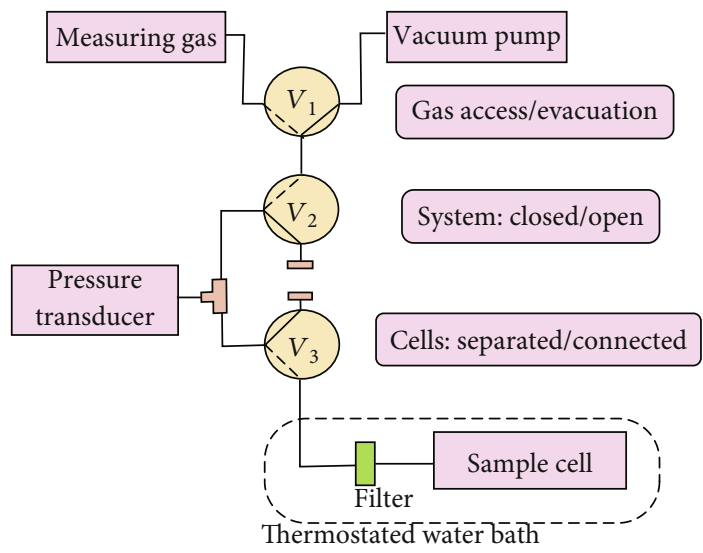

(b)

Figure 2: An experimental volumetric setup for analyzing methane in coal.

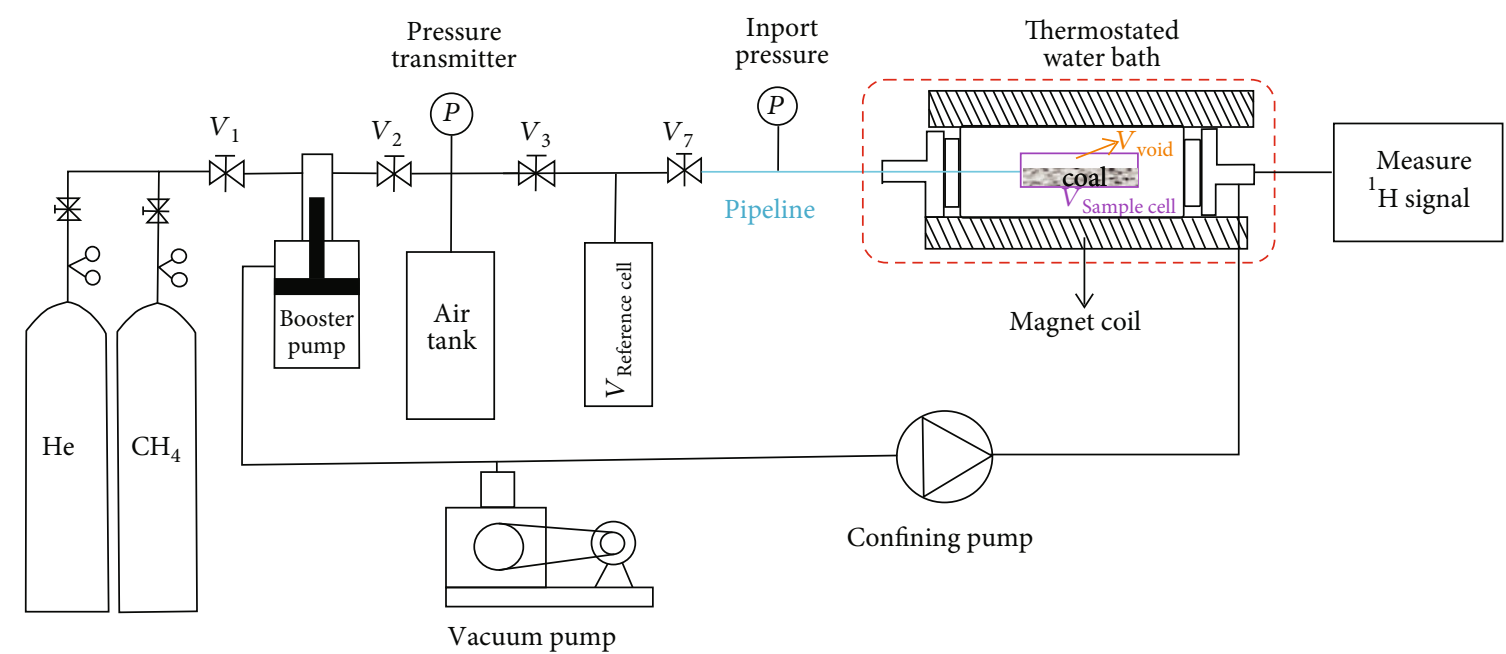

Figure 3: An experimental low-field NMR setup for analyzing methane in coals.

the problems mentioned above were analyzed based on the experimental results of seven coal samples in medium-rank range according to the volumetric method, Yao et al.'s lowfield NMR method [49], and our modified low-field NMR method, respectively.

\section{Sample and Methods}

2.1. Sample Preparation. Seven fresh block samples were obtained from underground coal mines (Malan mine (ML), Tunlan mine (TL), Dongqu mine (DQ), Xiqu mine (XQ), Ximing mine $(\mathrm{XM})$, Zhenchengdi mine (ZCD), and Duerping mine (DEP)) in the Xishan coalfield, China (Figure 1). Each sample was crushed and sieved into a size range of $0.18-0.25 \mathrm{~mm}$ and $0.1 \mathrm{~mm}$ to $1 \mathrm{~mm}$ for methane isotherm adsorption and vitrinite reflectance $\left(R_{0}\right)$ measurements, respectively.
TABLE 1: Vitrinite reflectance $\left(R_{\mathrm{o}}\right)$ and maceral and mineral of the samples.

\begin{tabular}{lccccc}
\hline $\begin{array}{l}\text { Sample } \\
\text { ID }\end{array}$ & $\begin{array}{c}\text { Vitrinite } \\
\text { reflectance } \\
\left(R_{\mathrm{o}} \%\right)\end{array}$ & \multicolumn{3}{c}{ Maceral and mineral (vol.\%) } \\
\hline ML-2 & 1.08 & 76.8 & 21.2 & - & 2.0 \\
ZCD-2 & 1.21 & 66.9 & 32.3 & - & 0.8 \\
TL-2 & 1.24 & 74.9 & 24.7 & & 0.4 \\
XQ-2 & 1.32 & 64.0 & 35.2 & & 0.8 \\
XM-2 & 1.61 & 61.2 & 35.6 & - & 3.2 \\
DEP-3 & 1.71 & 75.2 & 22.8 & - & 2.0 \\
DQ-2 & 1.80 & 68.7 & 31.0 & - & 0.3 \\
\hline
\end{tabular}

2.2. Volumetric Method. According to GB/T 19560-2008, the experiment of methane adsorption using the volumetric method was accomplished. The volumetric apparatus mainly 
TABLE 2: Measurements of the amounts of methane adsorbed on the coal samples as determined by the volumetric method.

\begin{tabular}{|c|c|c|c|c|c|c|c|}
\hline \multirow{2}{*}{ Sample } & \multirow{2}{*}{ Parameter } & \multicolumn{6}{|c|}{ Sequence } \\
\hline & & 1 & 2 & 3 & 4 & 5 & 6 \\
\hline \multirow{2}{*}{ ML } & $P(\mathrm{MPa})$ & 0.618 & 1.095 & 2.245 & 3.814 & 6.017 & 7.518 \\
\hline & $V\left(\mathrm{~m}^{3} / \mathrm{t}\right)$ & 3.378 & 5.807 & 9.279 & 11.971 & 13.900 & 14.197 \\
\hline \multirow{2}{*}{$\mathrm{ZCD}$} & $P(\mathrm{MPa})$ & 0.697 & 1.205 & 2.337 & 3.822 & 5.983 & 7.581 \\
\hline & $V\left(\mathrm{~m}^{3} / \mathrm{t}\right)$ & 3.527 & 5.593 & 8.341 & 11.005 & 12.959 & 15.088 \\
\hline \multirow{2}{*}{$\mathrm{TL}$} & $P(\mathrm{MPa})$ & 0.695 & 1.251 & 2.405 & 3.809 & 6.082 & 1.793 \\
\hline & $V\left(\mathrm{~m}^{3} / \mathrm{t}\right)$ & 5.464 & 7.892 & 11.043 & 13.149 & 15.416 & 17.546 \\
\hline \multirow{2}{*}{ XQ } & $P(\mathrm{MPa})$ & 0.625 & 1.141 & 2.249 & 3.682 & 5.980 & 7.642 \\
\hline & $V\left(\mathrm{~m}^{3} / \mathrm{t}\right)$ & 3.574 & 6.278 & 9.531 & 12.321 & 14.424 & 15.546 \\
\hline \multirow{2}{*}{$\mathrm{XM}$} & $P(\mathrm{MPa})$ & 0.563 & 1.060 & 2.172 & 3.764 & 5.902 & 7.846 \\
\hline & $V\left(\mathrm{~m}^{3} / \mathrm{t}\right)$ & 3.918 & 6.410 & 10.919 & 14.198 & 16.211 & 18.653 \\
\hline \multirow{2}{*}{ DEP } & $P(\mathrm{MPa})$ & 0.672 & 1.172 & 2.241 & 3.927 & 6.016 & 7.643 \\
\hline & $V\left(\mathrm{~m}^{3} / \mathrm{t}\right)$ & 5.426 & 8.306 & 11.763 & 14.781 & 17.039 & 19.573 \\
\hline \multirow{2}{*}{ DQ } & $P(\mathrm{MPa})$ & 0.699 & 1.172 & 2.301 & 3.994 & 6.039 & 7.669 \\
\hline & $V\left(\mathrm{~m}^{3} / \mathrm{t}\right)$ & 6.543 & 11.544 & 16.104 & 19.938 & 22.739 & 24.585 \\
\hline
\end{tabular}
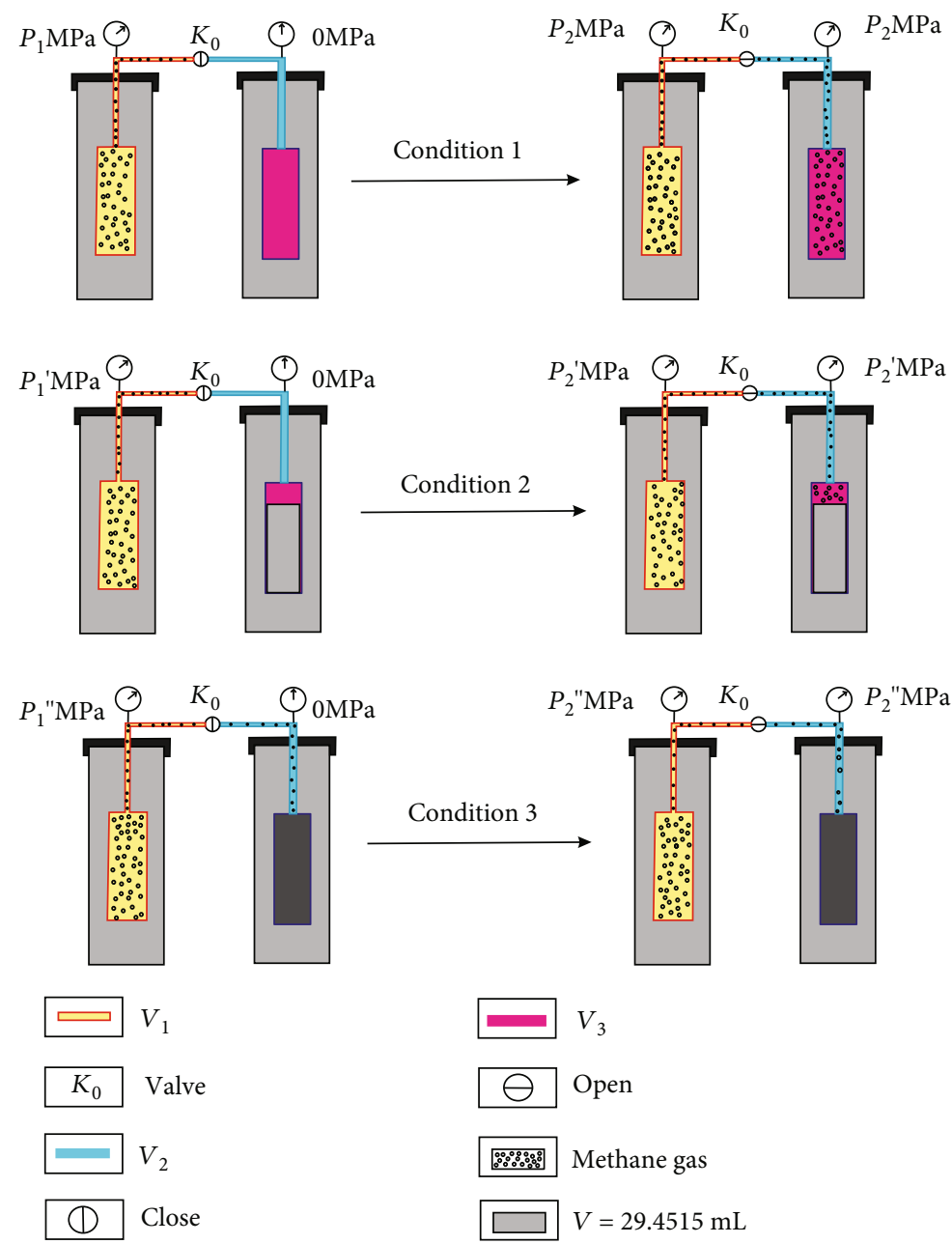

FIGURE 4: Schematic procedures for calculating the volumes of the reference cell, pipeline, and sample cell by the modified low-field NMR method. 
TABle 3: Data of the volumes of the reference cell, sample cell, and pipeline from the modified low-field NMR method.

\begin{tabular}{|c|c|c|c|c|c|c|c|}
\hline \multirow{2}{*}{ Sequence } & & \multicolumn{3}{|c|}{ Condition } & \multicolumn{3}{|c|}{ Parameters } \\
\hline & & 1 & 2 & 3 & $V_{1}$ & $V_{2}$ & $V_{3}$ \\
\hline \multirow[b]{2}{*}{ First time } & $P_{\mathrm{i}}(\mathrm{MPa})$ & 1.62 & 1.99 & 1.89 & \multirow[b]{2}{*}{39.6693} & \multirow[b]{2}{*}{8.0854} & \multirow{2}{*}{41.5012} \\
\hline & $P_{\mathrm{e}}(\mathrm{MPa})$ & 0.72 & 1.32 & 1.57 & & & \\
\hline \multirow{2}{*}{ Second time } & $P_{\mathrm{i}}(\mathrm{MPa})$ & 2.51 & 1.72 & 2.19 & \multirow{2}{*}{38.6185} & \multirow{2}{*}{7.8713} & \multirow{2}{*}{41.4746} \\
\hline & $P_{\mathrm{e}}(\mathrm{MPa})$ & 1.12 & 1.14 & 1.83 & & & \\
\hline \multirow{2}{*}{ Third time } & $P_{\mathrm{i}}(\mathrm{MPa})$ & 2.56 & 2.65 & 2.72 & \multirow{2}{*}{38.7619} & \multirow{2}{*}{8.3061} & \multirow{2}{*}{40.7465} \\
\hline & $P_{\mathrm{e}}(\mathrm{MPa})$ & 1.13 & 1.76 & 2.24 & & & \\
\hline \multicolumn{5}{|c|}{ Average } & 39.0166 & 8.0876 & 41.2407 \\
\hline
\end{tabular}

$P_{\mathrm{i}}$ and $P_{\mathrm{e}}$ stand for the injection pressure and equilibrium pressure, respectively.

includes the reference cell, sample cell, and temperature control system (Figure 2(a)). Figure 2(b) is a simplified diagram of the volumetric method. At constant temperature of $30^{\circ} \mathrm{C}$, the Langmuir volume of adsorbed methane was calculated under a dry basis. The theoretical background and experimental procedures for the volumetric method of gas adsorption isotherms on coal are discussed in detail in the literature $[22,26]$. This experiment was conducted in the North China Petroleum Technology Service using the ISO-300 ISOTHERM DESORPTION instrument.

2.3. Low-Field NMR Relaxation Method. The low-field NMR measurement apparatus used in this study is a MacroMR12$150 \mathrm{H}-\mathrm{I}$ spectrometer, manufactured by Niumag Corporation Ltd., China. The instrument has a frequency of $12.98 \mathrm{MHz}$, a magnetic strength of $0.5 \mathrm{~T}$, and a magnet coil with the diameter of $60 \mathrm{~mm}$. The magnetic uniformity is as low as $30 \mathrm{ppm}$, and relaxation from gas diffusion could be ignored. Figure 3 is a simplified diagram of low-field NMR, mainly consisting of five parts: a gas supply system, a booster pump, a vacuum pump, a NMR measurement apparatus, and a temperature control device.

In this study, a Carr-Purcell-Meiboom-Gill (CPMG) sequence was used for measuring transverse relaxation times $\left(T_{2}\right)$. The CPMG measurement parameters were appropriately set to maximize the amount of information acquired for coal samples. The parameters echo spacing $\left(T_{\mathrm{E}}\right)$ and number of trains (NS) for the NMR experiment were $0.2 \mathrm{~ms}$ and 64 , respectively. The wait time of $5000 \mathrm{~ms}$ and number of echoes (NECH) of 18000 were used to ensure that the complete decay curve would be recorded. The experimental procedures were as follows:

First, some helium with pressure less than $3 \mathrm{MPa}$ was injected into the reference cell, and wait for five hours to check air tightness. Second, three conditions were set to calculate the volume of the reference cell, pipeline, and sample cell. Third, methane gas was injected into the sample cell to check for methane signal. A relationship between the mass of bulk methane and amplitude was built at a constant temperature of $30^{\circ} \mathrm{C}$. After that, the coal samples which had been dried in a dry box at $110^{\circ} \mathrm{C}$ for 1 hour were loaded into the sample cell. Then, methane gas was injected into the sample cell for adsorption measurements. Finally, the low-field NMR measurement of the sample cell was conducted with a time
TABLE 4: Experimental result of mass and amplitude of bulk methane by the modified low-field NMR method.

\begin{tabular}{lccccc}
\hline$P(\mathrm{MPa})$ & 1.05 & 2.40 & 4.40 & 6.45 & 7.74 \\
Mass $(\mathrm{g})$ & 0.2875 & 0.6718 & 1.2715 & 1.9231 & 2.3503 \\
Relaxation area & 3292.59 & 6616.73 & 12339.10 & 18419.58 & 21850.10 \\
\hline
\end{tabular}

interval of $1 \mathrm{~h}$ until two successive results had negligible fluctuation.

Seven coal samples were computed independently at six different pressures by repeating the experimental procedures above. Every sample placed in the sample cell was in the range of 28 to $30 \mathrm{~g}$.

2.4. The Theory of NMR Measurements for Methane Gas. Nuclear magnetic resonance occurs when the nucleus of a hydrogen proton (i.e., water, gas, and oil) enters the static magnetic field magnetization and the RF plus gradient field excitation. Using the relaxation distribution and the relaxation time, the number of hydrogen atoms in the methane gas would be detected.

According to the basic principle of rock nuclear magnetic resonance measurement, the $T_{2}$ is affected by the relaxation times of bulk, surface, and diffusion relaxations [50,51]; thus,

$$
\frac{1}{T_{2}}=\frac{1}{T_{2 \mathrm{~B}}}+\frac{1}{T_{2 \mathrm{~S}}}+\frac{1}{T_{2 \mathrm{D}}},
$$

where subscripts $B, S$, and D refer to bulk, surface, and diffuse relaxation, respectively. The CPMG pulse sequence measurement is used to obtain the $T_{2}$ relaxation under fast diffusion condition. The influence of diffusion relaxation can be ignored as the magnetic field is uniform $[48,49]$. The bulk relaxation is an intrinsic property of the hydrogencontaining fluid and affected by the physical properties. Thus, the bulk relaxation $\left(T_{2 \mathrm{~B}}\right)$ of gas does not need to be considered. Coates et al. [52] pointed that the relaxation of methane $\left(T_{2 S}\right)$ gas is controlled by the surface relaxation, and equation (1) becomes

$$
\frac{1}{T_{2}}=\frac{1}{T_{2 S}}=\rho \frac{S}{V}=F_{s} \frac{\rho}{r},
$$




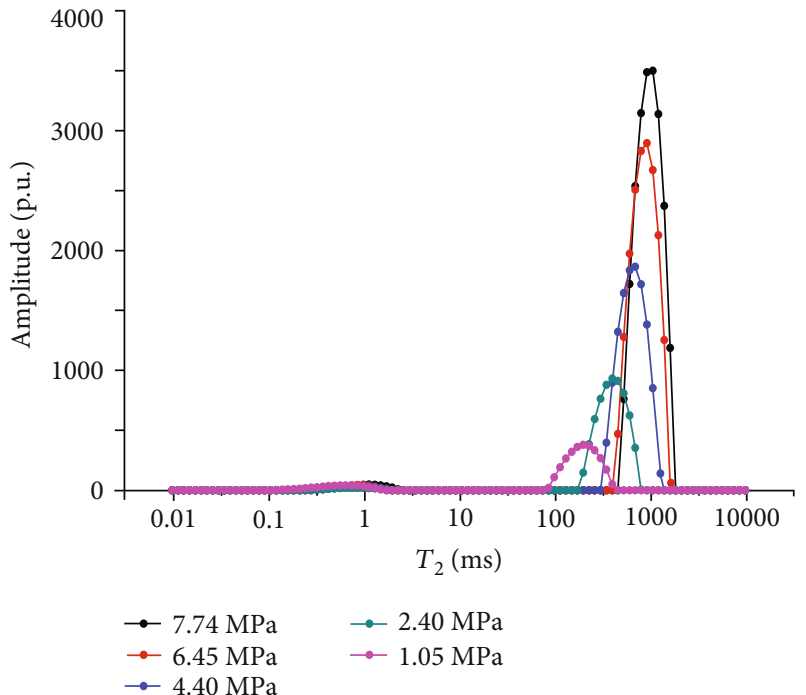

(a)

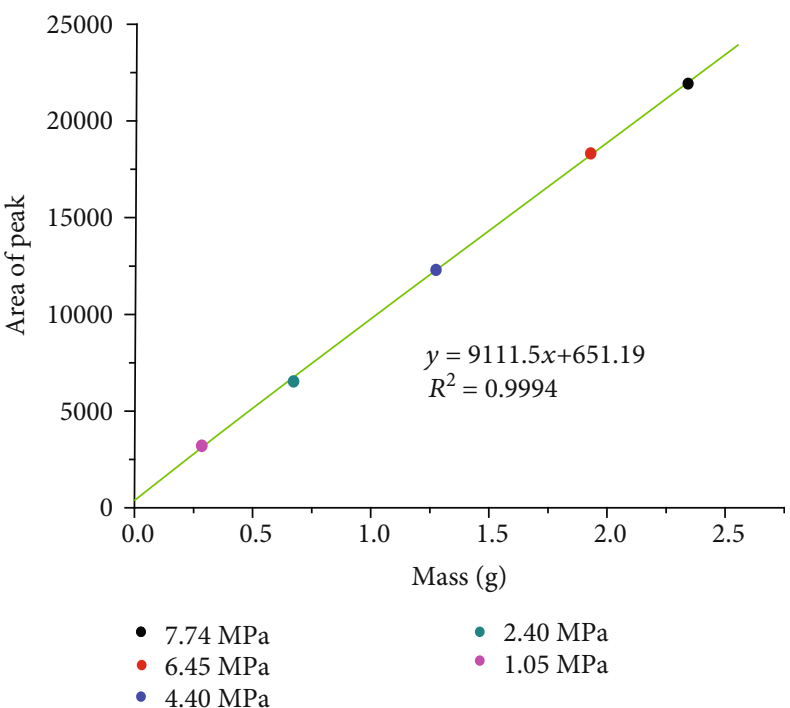

(b)

Figure 5: Low-field NMR measurements for bulk methane at different pressures.

where $\rho$ is the surface relaxivity, $S / V$ is the surface-to-volume ratio of the pore, $F_{s}$ is the shape geometry factor $\left(F_{s}\right.$ of the spherical hole and columnar pipe are 3 and 2, respectively), and the shape of the pore can be converted into a relationship with the radius.

\section{Result}

3.1. Characteristics of Coal Samples. The vitrinite reflectance $\left(R_{\mathrm{o}}\right)$ measurements were acquired using a Zeiss Axioskop 40 A photometer microscope, following conventional methods according to China National Standards GB/T 6948-2008 [53]. The mean maximum vitrinite reflectance $\left(R_{\mathrm{o}}\right)$ data of seven coal samples ranges from $1.08 \%$ to $1.80 \%$, as shown in Table 1. Meanwhile, the vitrinite accounts for between 61.2 and $76.8 \%$, while inertinite ranges from 21.2 to $35.6 \%$, and almost no liptinite is present. The proportion of mineral matter (visible) ranges from 0.3 to $3.2 \%$.

3.2. The Result of Methane Adsorption by the Volumetric Method. The results of methane adsorption experiment from the volumetric method are shown in Table 2. The volume of adsorbed methane was calculated and translated to the volume of methane at the standard state $\left(101.325 \mathrm{~Pa}, 0^{\circ} \mathrm{C}\right)$.

\subsection{Results by the Modified Low-Field NMR Method}

3.3.1. The Volumes of the Reference Cell, Sample Cell, and Pipeline. The volumes of each part of the test system are the fundamental parameters for calculating methane adsorption volume using the modified low-field NMR method. Yao et al. [49] pointed that a small degree of helium sorption (which cannot be excluded but also not quantified) might lead to an underestimation of the sample cell volume for both methods. So, methane gas was used to minimize this deviation in this experiment. Three assumed conditions were designed to calculate the volumes of the sample cell, reference cell, and pipeline. The calculation procedure is as follows (Figure 4).

Condition 1 . The sample cell is empty with the valve $\left(K_{0}\right)$ between the reference cell and sample cell closed. Then, methane gas was injected into the reference cell at a certain pressure $P_{1}$. After injection, the valve $\left(K_{0}\right)$ turned to open. The equilibrium pressure was recorded as $P_{2}$. A calculation formula in this condition then gives

$$
P_{1} V_{1}=P_{2}\left(V_{1}+V_{2}+V_{3}\right) \text {, }
$$

where $V_{1}$ is the volume of the reference cell, $V_{2}$ is the volume of the pipeline, and $V_{3}$ is the volume of the sample cell.

Condition 2. A certain volume cylinder $(29.4515 \mathrm{~mL})$ was put in the sample cell; then, the operation mentioned above was repeated. The calculation formula in this condition is

$$
P_{1}^{\prime} V_{1}=P_{2}{ }^{\prime}\left(V_{1}+V_{2}+V_{3}-29.4515\right),
$$

where $P_{1}{ }^{\prime}$ and $P_{2}{ }^{\prime}$ stand for the injection pressure and equilibrium pressure in condition 2 , respectively.

Condition 3. The sample cell was replaced by a fulfilled cell $\left(V_{3}\right.$ is $0 \mathrm{~cm}^{3}$ in this assumed condition). By repeating the pressure operation mentioned above, the calculation formula turns into

$$
P_{1}^{\prime \prime} V_{1}=P_{2}^{\prime \prime}\left(V_{1}+V_{2}\right),
$$

where $P_{1}{ }^{\prime \prime}$ and $P_{2}{ }^{\prime \prime}$ stand for the injection pressure and equilibrium pressure in condition 3 , respectively.

According to equations (3)-(5), the volumes of the sample cell, reference cell, and pipeline were calculated (Table 3 ).

The pressure operation processes (conditions 1-3) were repeated three times to minimize experiment deviation (Table 3). 


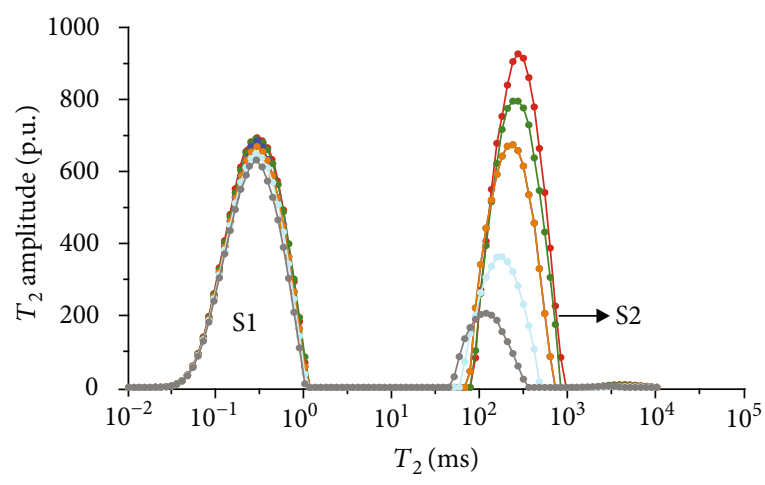

S1 the area of absurbed methane S2 the area of bulk methane

$\begin{array}{ll}\because-7.73 \mathrm{MPa} & \because-6.63 \mathrm{MPa} \\ \because-6.05 \mathrm{MPa} & \because-61 \mathrm{MPa} \\ \rightarrow-1.70 \mathrm{MPa} & \end{array}$

(a)

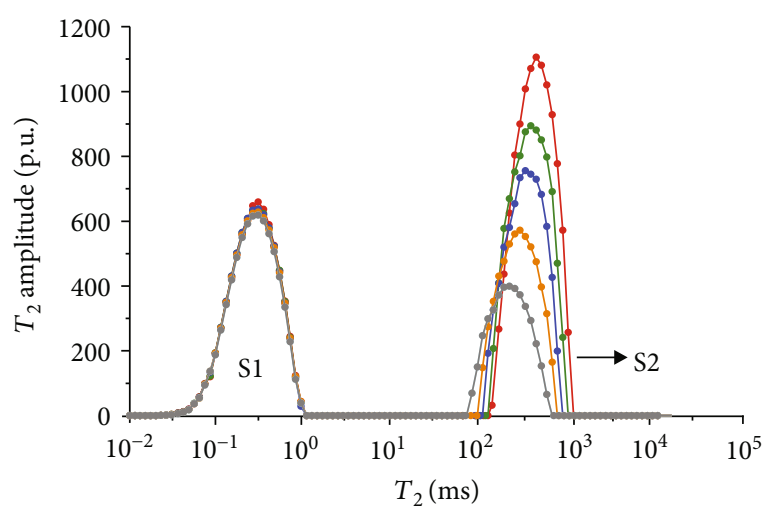

S1 the area of absurbed methane S2 the area of bulk methane

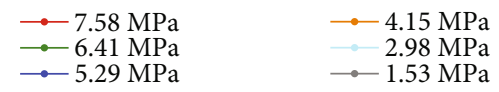

(c)

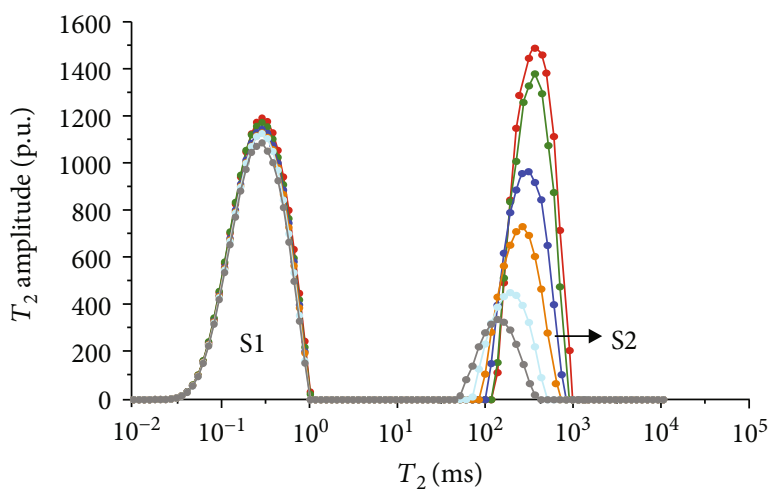

S1 the area of absurbed methane S2 the area of bulk methane

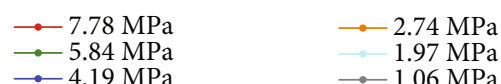

(e)

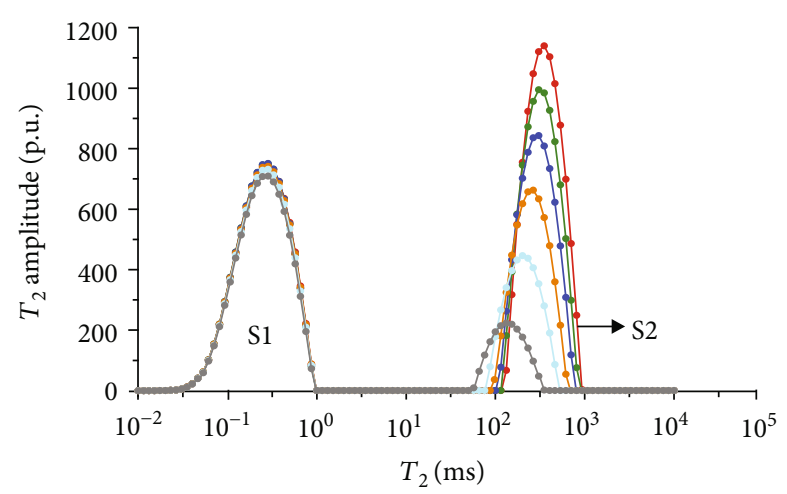

S1 the area of absurbed methane S2 the area of bulk methane

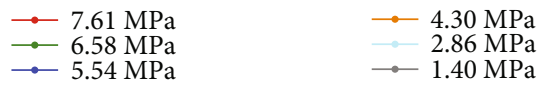

(b)

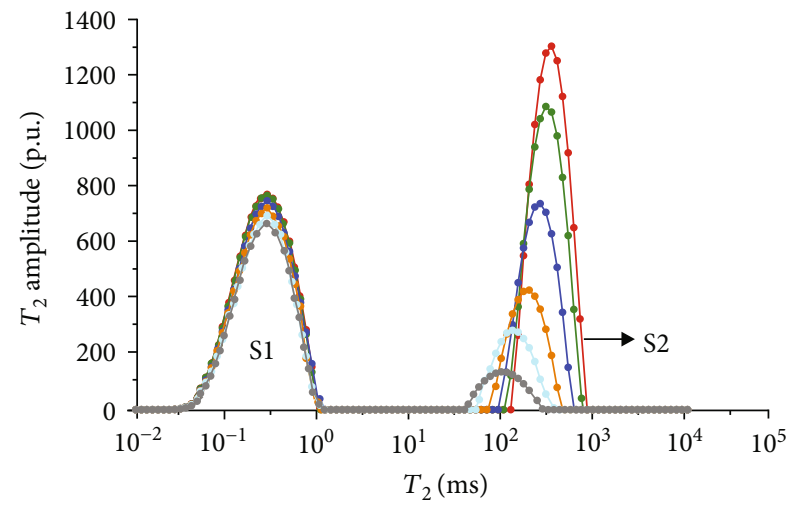

S1 the area of absurbed methane S2 the area of bulk methane

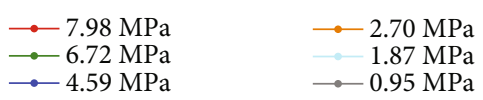

(d)

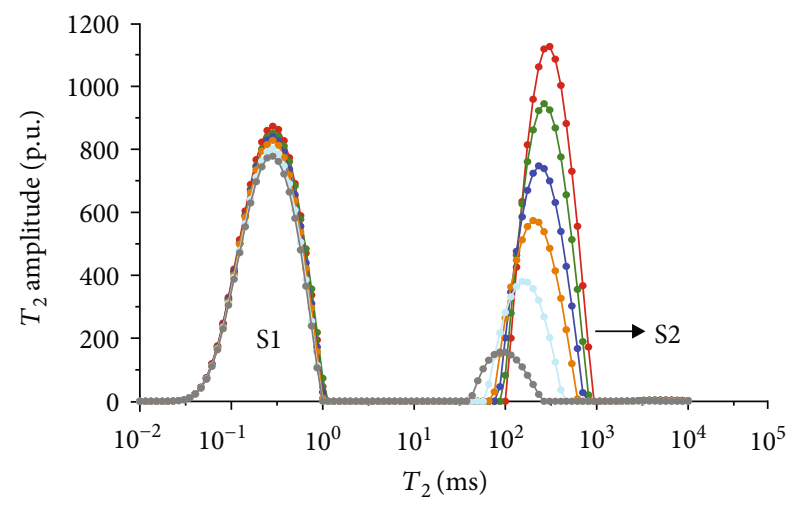

S1 the area of absurbed methane S2 the area of bulk methane

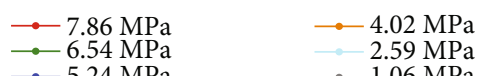

(f)

FIgURe 6: Continued. 


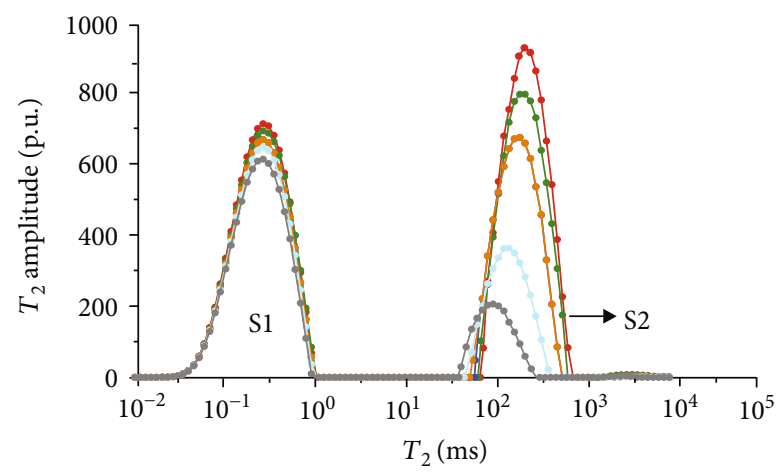

S1 the area of absurbed methane

S2 the area of bulk methane

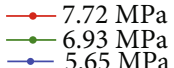

$\because 6.93 \mathrm{MPa}$

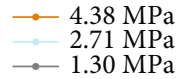

(g)

Figure 6: $T_{2}$ spectra for methane at different pressures for seven coal samples.

3.3.2. The Relaxation Properties of Bulk Methane. In this study, the low-field NMR apparatus was applied to measure the relaxation of bulk methane gas at gas pressures of 0.91 , $3.09,6.35,10.05$, and $12.75 \mathrm{MPa}$ while all measurements were conducted in condition of a constant temperature $\left(30^{\circ} \mathrm{C}\right)$. The results of the low-field NMR relaxation of bulk methane are shown in Table 4 . The bulk methane mass can be obtained by using an equation of state (EOS).

$$
P V=\frac{Z m R T}{M}
$$

where $P$ is the gas pressure, $V$ is the volume of the sample cell, $Z$ is the gas compression factor at the pressure, $m$ is the mass of methane, $R$ is the Avogadro constant (8.314), $T$ is the temperature $(303.15 \mathrm{~K})$, and $M$ is the methane molecular mass constant (16).

As shown in Figure 5(a), the relaxation time of bulk methane is relatively large, which exhibits an obvious peak at $70 \mathrm{~ms}-2000 \mathrm{~ms}$. The relaxation area and relaxation times of bulk methane gradually increase with the increase in pressure, which is consistent with the work of Guo et al. [48] and Yao et al. [49, 50]. Morriss et al. [51] proved that the mean free path of methane molecules declines with the increase in pressure, which results in the increase in bulk methane relaxation time.

The signal amplitude of $T_{2}$ is closely linked to bulk relaxation and thus to the number of ${ }^{1} \mathrm{H}$ protons. Therefore, the signal amplitude of $T_{2}$ increased linearly with the mass of methane. The mass of bulk methane was calculated based on the pressure data (equation (6)). Then, a relationship between the mass of bulk methane and the peak area of the $T_{2}$ spectrum was established. Figure 5(b) indicates that there is a distinct linear correlation between $T_{2}$ amplitude and mass of bulk methane. Thus, the mass of bulk methane gas can be calculated using this linear relationship.

$$
m_{\mathrm{v}}=9111.5^{*} S_{T}+651.19(R=0.9994) \text {, }
$$

where $m_{\mathrm{v}}$ is the mass of bulk methane in the sample cell and $S_{T}$ is the peak area of the $T_{2}$ spectrum.

3.3.3. The Relaxation Properties of Methane in Coal. In this experiment, six random pressures were selected between 0 and $8 \mathrm{MPa}$. The methane isotherm adsorption of coal samples was carried out according to the steps mentioned in Section 2.

Figure 6 shows the methane relaxation spectra of seven samples at different pressures. Compared to the $T_{2}$ spectra of bulk methane, these spectra show a bimodal structure. This indicates that there are two different relaxations of methane (S1 and S2). The methane relaxation time in micropores is faster than that in macropores as a response for pore radius (equation (2)). Therefore, the relaxation area of the second peak (S2) represents bulk methane in macropores ( $T_{2}$ relaxation time is between $75 \mathrm{~ms}$ and $1000 \mathrm{~ms}$ ), and the relaxation area of the first peak (S1) represents adsorbed methane in micropores or on the surface of the coal matrix ( $T_{2}$ relaxation time is $<1 \mathrm{~ms}$ ). As the pressure increases, the starting value of relaxation time represents that adsorbed methane does not change while bulk methane increases. The peak position of each spectrum shows the similar characteristic with a starting value, which indicates that the pressure has no influence on the methane relaxation in the adsorbed phase.

3.3.4. The Methane Adsorption by Modified Low-Field NMR. Firstly, the total mass of methane $\left(m_{\text {total }}\right)$ was computed by equation (6). Then, after equilibrium adsorption, the mass of the methane in the reference cell and pipeline $\left(m_{\mathrm{r}}\right.$ and $m_{\mathrm{p}}$ ) was calculated by equation (6), and the mass of bulk methane in the sample cell $\left(m_{\mathrm{v}}\right)$ was calculated by equation (7), respectively. Finally, the mass of adsorbed methane (Table 5) was obtained using the following equation.

$$
m_{\mathrm{a}}=m_{\text {total }}-m_{\mathrm{r}}-m_{\mathrm{p}}-m_{\mathrm{v}}
$$


TABLE 5: Results of the adsorbed methane on the coal samples determined by the low-field NMR method.

\begin{tabular}{|c|c|c|c|c|c|c|c|}
\hline \multirow{2}{*}{ Sample } & \multirow{2}{*}{ Parameters } & \multicolumn{6}{|c|}{ Sequence } \\
\hline & & 1 & 2 & 3 & 4 & 5 & 6 \\
\hline \multirow{3}{*}{ ML } & $P(\mathrm{MPa})$ & 1.19 & 2.61 & 3.63 & 4.70 & 6.05 & 7.73 \\
\hline & S1 & 7897.07 & 8424.60 & 8796.56 & 8746.33 & 9179.86 & 9341.07 \\
\hline & $V^{*}\left(\mathrm{~m}^{3} / \mathrm{t}\right)$ & 6.479 & 10.090 & 11.394 & 12.288 & 13.252 & 14.779 \\
\hline \multirow{3}{*}{ ZCD } & $P(\mathrm{MPa})$ & 1.40 & 2.86 & 4.30 & 5.54 & 6.58 & 7.61 \\
\hline & S1 & 8935.66 & 9224.92 & 9391.05 & 9450.81 & 9444.28 & 9431.63 \\
\hline & $V^{*}\left(\mathrm{~m}^{3} / \mathrm{t}\right)$ & 6.599 & 9.833 & 11.620 & 12.976 & 14.059 & 14.948 \\
\hline \multirow{3}{*}{$\mathrm{TL}$} & $P(\mathrm{MPa})$ & 1.39 & 2.80 & 4.06 & 5.20 & 6.30 & 7.54 \\
\hline & S1 & 1704.017 & 3933.606 & 5624.065 & 7407.862 & 9207.367 & 11112.86 \\
\hline & $V^{*}\left(\mathrm{~m}^{3} / \mathrm{t}\right)$ & 7.620 & 11.659 & 13.077 & 14.210 & 15.360 & 16.076 \\
\hline \multirow{3}{*}{ XQ } & $P(\mathrm{MPa})$ & 0.95 & 1.87 & 2.70 & 4.59 & 6.72 & 7.98 \\
\hline & S1 & 3594.01 & 9297.04 & 9314.20 & 10060.46 & 10062.72 & 10032.34 \\
\hline & $V^{*}\left(\mathrm{~m}^{3} / \mathrm{t}\right)$ & 5.355 & 8.493 & 10.397 & 12.773 & 14.742 & 16.089 \\
\hline \multirow{3}{*}{$\mathrm{XM}$} & $P(\mathrm{MPa})$ & 0.97 & 1.97 & 2.74 & 4.19 & 5.84 & 7.78 \\
\hline & S1 & 13403.84 & 14419.56 & 14586.88 & 14808.96 & 15510.67 & 15556.58 \\
\hline & $V^{*}\left(\mathrm{~m}^{3} / \mathrm{t}\right)$ & 6.073 & 9.685 & 11.575 & 13.830 & 15.757 & 17.372 \\
\hline \multirow{3}{*}{ DEP } & $P(\mathrm{MPa})$ & 1.06 & 2.59 & 4.02 & 5.24 & 6.54 & 7.86 \\
\hline & S1 & 9913.70 & 10210.35 & 10476.55 & 10911.88 & 11332.63 & 11377.45 \\
\hline & $V^{*}\left(\mathrm{~m}^{3} / \mathrm{t}\right)$ & 7.940 & 11.095 & 14.480 & 16.720 & 17.660 & 18.802 \\
\hline \multirow{3}{*}{ DQ } & $P(\mathrm{MPa})$ & 1.30 & 2.71 & 4.38 & 5.65 & 6.93 & 7.72 \\
\hline & S1 & 9533.81 & 9830.48 & 10296.58 & 10531.93 & 10872.74 & 10997.56 \\
\hline & $V^{*}\left(\mathrm{~m}^{3} / \mathrm{t}\right)$ & 10988 & 15.506 & 19.860 & 21.093 & 23.314 & 23.810 \\
\hline
\end{tabular}

$V^{*}$ is the volume of adsorbed methane determined by the low-field NMR method.

TABLE 6: Comparison of the fits of the Langmuir adsorption parameters by the low-field NMR method and volumetric method.

\begin{tabular}{lcccccc}
\hline Sample & ML & ZCD & TL & XQ & XM & DEP \\
\hline$V_{\mathrm{L}}{ }^{\mathrm{a}}\left(\mathrm{m}^{3} / \mathrm{t}\right)$ & 19.76 & 21.64 & 21.98 & 21.28 & 25.64 & 25.13 \\
$V_{\mathrm{L}}^{\mathrm{b}}\left(\mathrm{m}^{3} / \mathrm{t}\right)$ & 16.37 & 19.42 & 16.61 & 19.92 & 21.01 & 21.19 \\
$V_{\mathrm{L}}^{\mathrm{c}}\left(\mathrm{m}^{3} / \mathrm{t}\right)$ & 18.90 & 20.61 & 21.19 & 20.49 & 25.06 & 25.00 \\
$P_{\mathrm{L}}^{\mathrm{a}}(\mathrm{MPa})$ & 2.69 & 3.63 & 2.30 & 2.82 & 3.10 & 2.15 \\
$P_{\mathrm{L}}^{\mathrm{b}}(\mathrm{MPa})$ & 2.35 & 3.18 & 1.64 & 1.93 & 2.50 & 31.85 \\
$P_{\mathrm{L}}{ }^{\mathrm{c}}(\mathrm{MPa})$ & 2.36 & 3.06 & 2.22 & 2.72 & 2.97 & 2.32 \\
$V_{\mathrm{L}}^{\mathrm{a}}-V_{\mathrm{L}}^{\mathrm{b}}\left(\mathrm{m}^{3} / \mathrm{t}\right)$ & 3.39 & 1.82 & 5.37 & 1.36 & 4.65 & 2.73 \\
$V_{\mathrm{L}}^{\mathrm{a}}-V_{\mathrm{L}}^{\mathrm{c}}\left(\mathrm{m}^{3} / \mathrm{t}\right)$ & 0.86 & 1.03 & 0.79 & 0.79 & 0.58 & 3.94 \\
$V_{\mathrm{L}}^{\mathrm{a}}-V_{\mathrm{L}}^{\mathrm{b}} / V_{\mathrm{L}}^{\mathrm{a}}(\%)$ & 17.18 & 5.79 & 24.42 & 6.37 & 18.07 & 0.13 \\
$V_{\mathrm{L}}^{\mathrm{a}}-V_{\mathrm{L}}^{\mathrm{c}} / V_{\mathrm{L}}^{\mathrm{a}}(\%)$ & $4.35 \%$ & $4.76 \%$ & $3.40 \%$ & $3.71 \%$ & $2.31 \%$ & 15.68 \\
\hline
\end{tabular}

${ }^{a}$ The result based on the volumetric method; ' the result based on Yao et al.'s method [49]; 'the result based on modified low-field NMR.

where $m_{\text {total }}$ is the total mass of methane, $m_{\mathrm{a}}$ is the mass of adsorbed methane, $m_{\mathrm{r}}$ is the mass of bulk methane in the reference cell, $m_{\mathrm{p}}$ is the mass of methane in the pipeline, and $m_{\mathrm{v}}$ is the mass of methane in the sample cell.

\section{Discussion}

4.1. The Suitability of the Modified Low-Field NMR Method. The low-field NMR as an in situ and dynamic method has been extensively applied to describe unconventional reservoir physical properties. In recent years, it is used to calculate the volume of adsorbed methane [50]. In contrast to the volumetric method, the low-field NMR modified method has many advantages.

Firstly, fewer mass of coal samples was required in the low-field NMR method (about $30 \mathrm{~g}$ ), while the volumetric method needs coal samples of $200 \mathrm{~g}$. Secondly, the low-field NMR method are mostly time saving. Thirdly, the pore size 


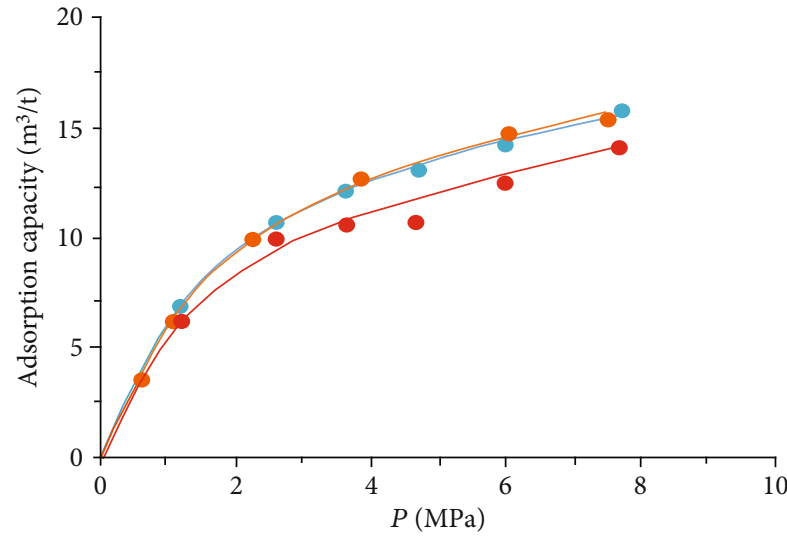

Data of volumetric method

- Data of NMR method explained by Yao's method

- Data of NMR method explained by modified method

(a) ML

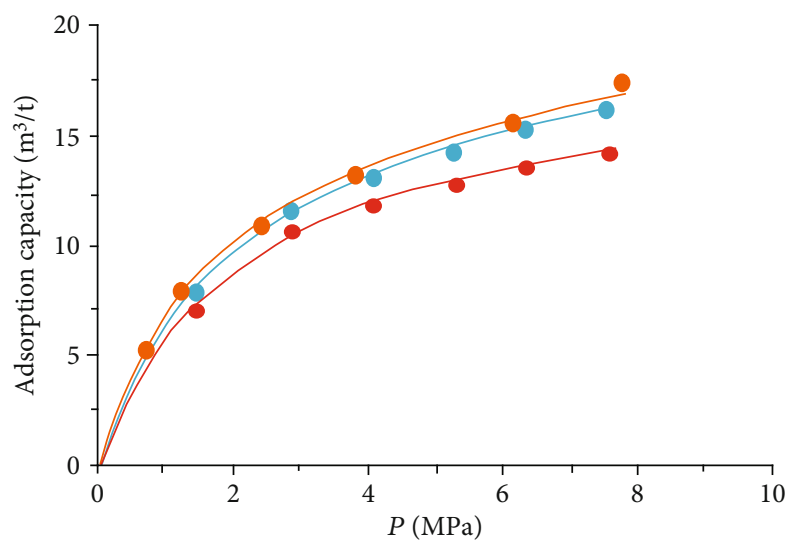

Data of volumetric method

- Data of NMR method explained by Yao's method

- Data of NMR method explained by modified method

(c) TL

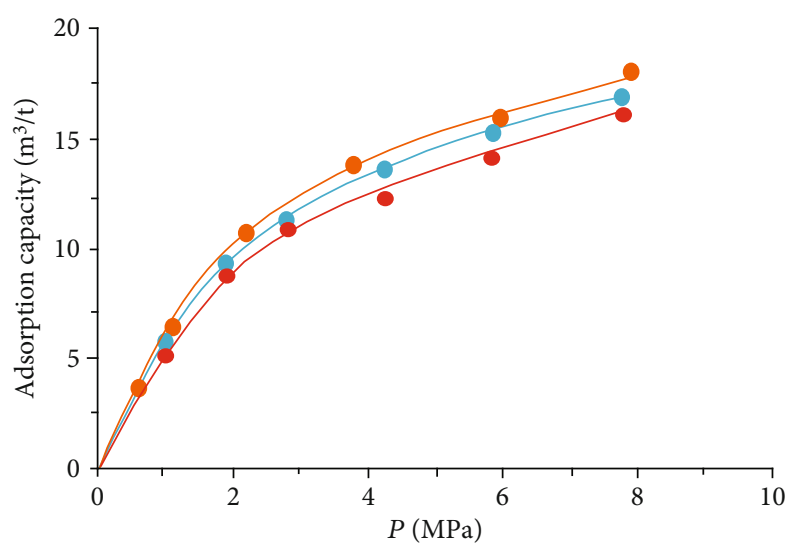

- Data of volumetric method

Data of NMR method explained by Yao's method

- Data of NMR method explained by modified method

(e) XM

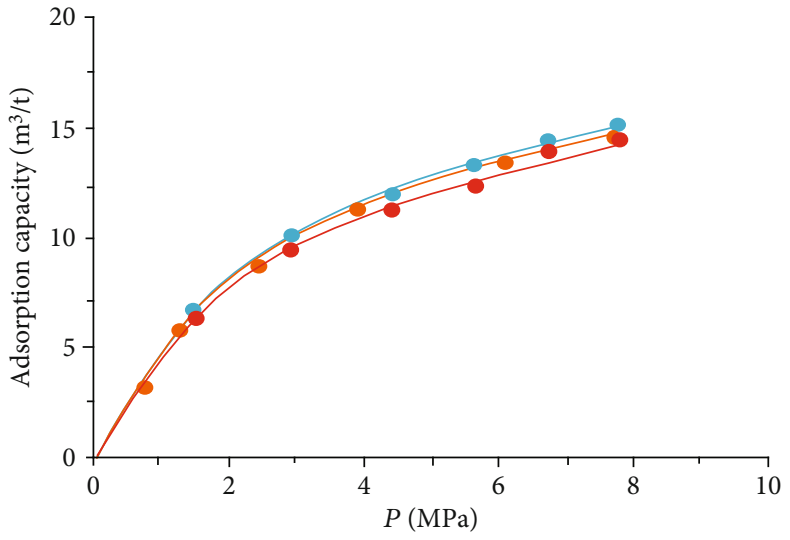

Data of volumetric method

Data of NMR method explained by Yao's method

- Data of NMR method explained by modified method

(b) ZCD

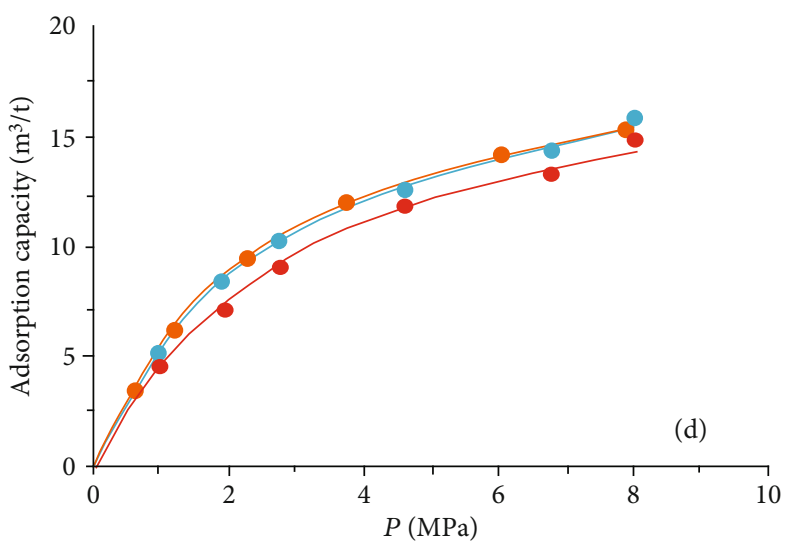

Data of volumetric method

Data of NMR method explained by Yao's method

- Data of NMR method explained by modified method

(d) XQ

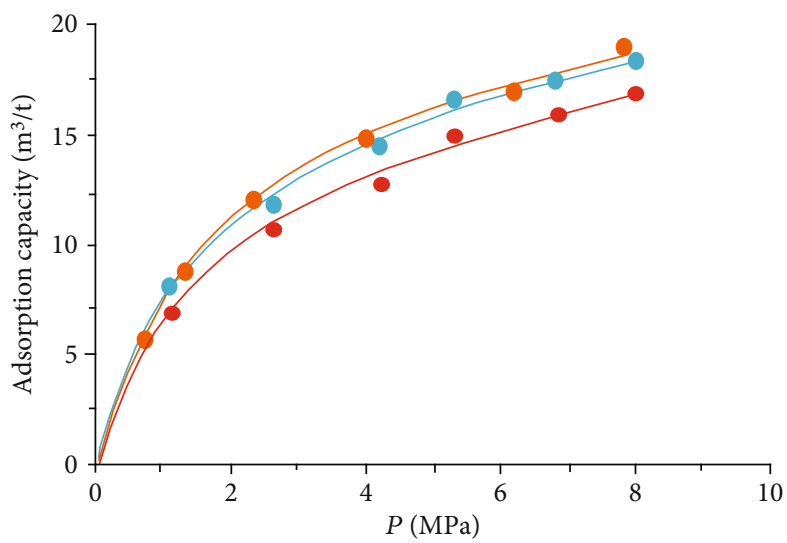

- Data of volumetric method

- Data of NMR method explained by Yao's method

- Data of NMR method explained by modified method

(f) DEP

FIgURe 7: Continued. 


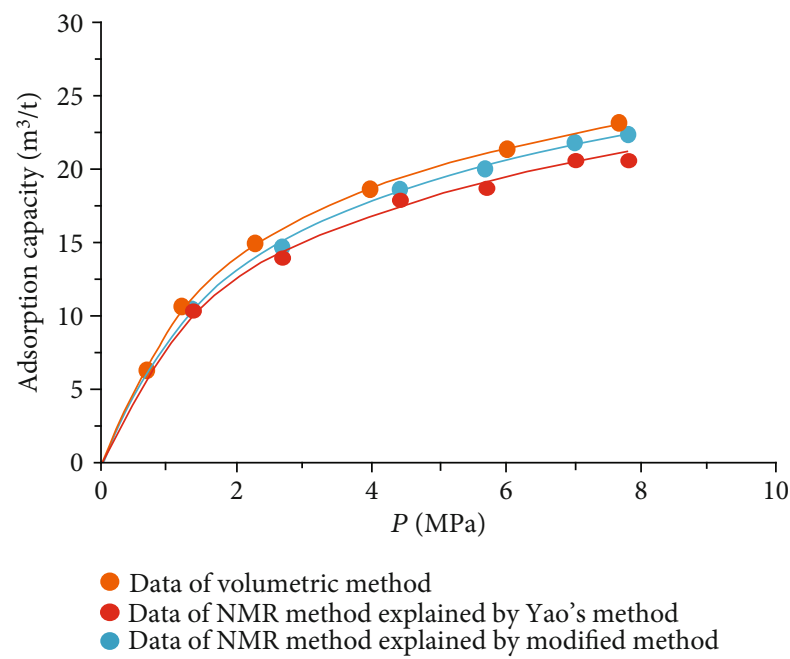

(g) DQ

FIGURE 7: Isothermal adsorption curves measured from the volumetric method, the modified low-field NMR method, and Yao et al.'s method (2014).

distribution of coal samples can be analyzed by the data of $T_{2}$ spectra. What is more, low-field NMR could perform realtime monitoring of the adsorption process.

In this research, the Langmuir volume $\left(V_{\mathrm{L}}\right)$ and Langmuir pressure $\left(P_{L}\right)$ were calculated using equation (9) based on the low-field NMR method (Table 5) comparing with $V_{\mathrm{L}}$ and $P_{\mathrm{L}}$ obtained from the volumetric method (Table 2).

$$
V_{\mathrm{vol}}=\frac{V_{\mathrm{L}} P}{\left(P+P_{\mathrm{L}}\right)},
$$

where $V_{\text {vol }}$ is the adsorbed volume $\left(\mathrm{m}^{3} / \mathrm{t}\right), V_{\mathrm{L}}$ is the Langmuir volume $\left(\mathrm{m}^{3} / \mathrm{t}\right), P$ is the equilibration pressure $(\mathrm{MPa})$, and $P_{\mathrm{L}}$ is the Langmuir pressure $(\mathrm{MPa})$.

The data of low-field NMR relaxation were processed according to Yao et al.'s low-field NMR method [49] and our modified low-field NMR method, respectively. The deviations between the results of the volumetric method and these two low-field NMR methods are shown in Table 6. The absolute deviations calculated according to Yao et al.'s method [49] vary from $1.36 \mathrm{~m}^{3} / \mathrm{t}$ to $5.37 \mathrm{~m}^{3} / \mathrm{t}$ while relative deviations range from 5.79 to $24.42 \%$. The absolute deviations from the modified NMR method fall in the range of $0.13-1.03 \mathrm{~m}^{3} / \mathrm{t}$ while relative deviations are $<4.76 \%$. The modified NMR method produced a relatively lower deviation compared with Yao et al.'s method [49], which indicates that the modified low-field NMR method is more suitable for measuring the amount of adsorbed methane (Figure 7).

It was also found that the result of the modified low-filed NMR method lightly underestimates that of the volumetric method (Figure 7). Three possible reasons may explain this phenomenon. Firstly, the temperature error of the sample cell holder may bring in influence on the signal of bulk methane. Secondly, the accuracy of low-field NMR instrument may result in deviations (i.e., the accuracy of the pressure gauge used in the NMR method is only 0.01, while the accuracy of the pressure gauge of the volumetric apparatus is 0.001). Moreover, for the needs of all sample cell signals are captured by the NMR system, a little part of the pipeline connected with the sample cell is also located in the magnet coil. These signals in this area may be treated as a signal of the sample cell during the relaxation signal collection. These signals would lead to an additional mass of bulk methane in the reference cell.

4.2. Adsorption Equilibration Time by Low-Field NMR. The volumetric method could not monitor the mass of adsorbed methane in real time. The adsorption equilibrium time can only be determined by monitoring pressure changes. But the low-field NMR method with a set time interval of signal collection can detect the methane adsorption dynamic process.

For each coal sample, six experiment pressures were set approximately homogeneous distributed in a range of 0 $8 \mathrm{MPa}$. Ten CPMG measurements were completed in each pressure condition. Figure 8 shows the integrated $T_{2}$ amplitudes of S1 ("adsorbed methane") as a function of time after methane addition for each sample. The $T_{2}$ amplitudes of adsorbed methane (S1) increase rapidly during the first four hours and then increase slowly in the following two or three hours. Finally, the $T_{2}$ amplitudes of adsorbed methane reached an essentially stable value, which indicates sample entering an equilibrium condition (Figure 8).

4.3. Pore Size Distribution in the Process of Adsorption. Previous researches proposed that micropores $(<2 \mathrm{~nm})$ and mesopores $(2-50 \mathrm{~nm})$ are significant for coalbed methane adsorption while macropores $(>50 \mathrm{~nm})$ mainly contribute spaces for free gas $[54,55]$. In this study, the pore size distribution for each sample was calculated from the NMR data using equation (2). As shown in Figure 9(a), the pore is 


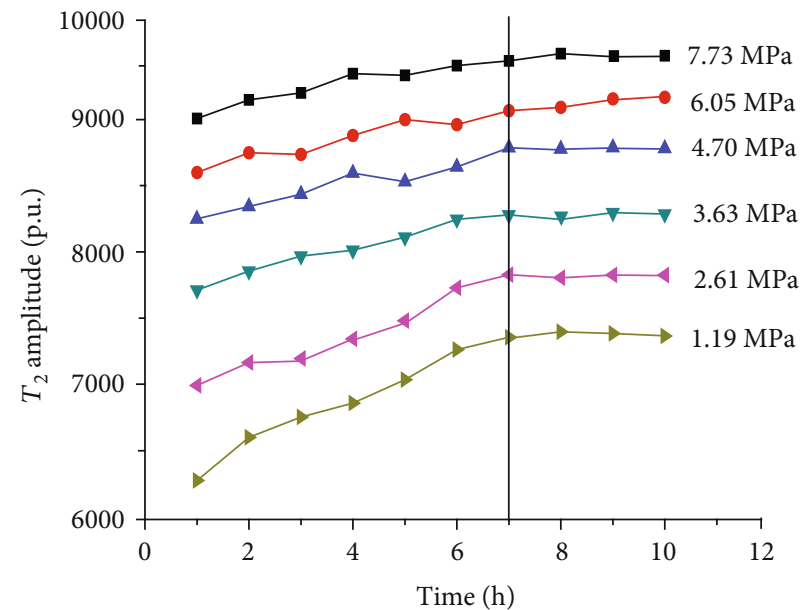

(a) $\mathrm{ML}$

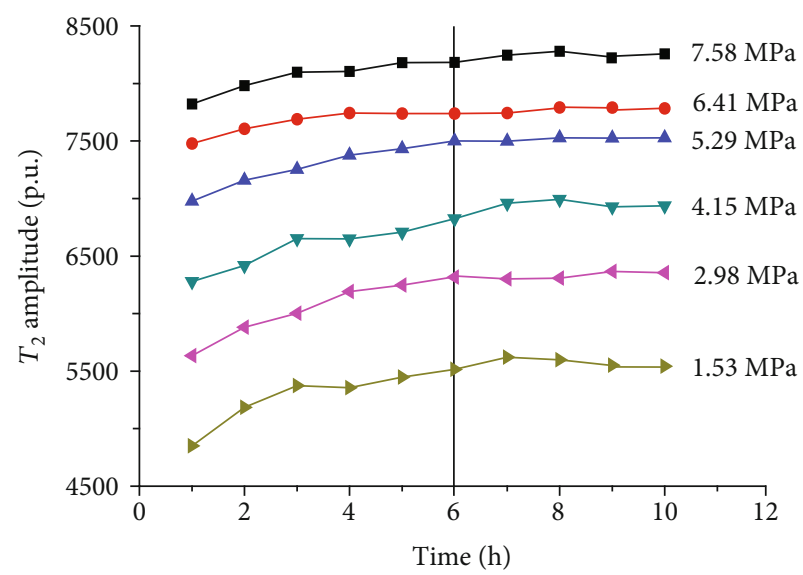

(c) TL

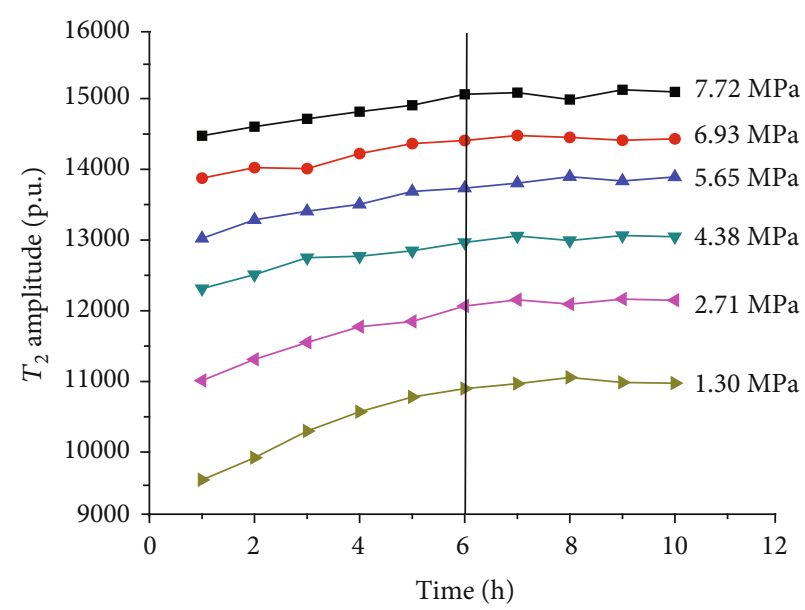

(e) XM

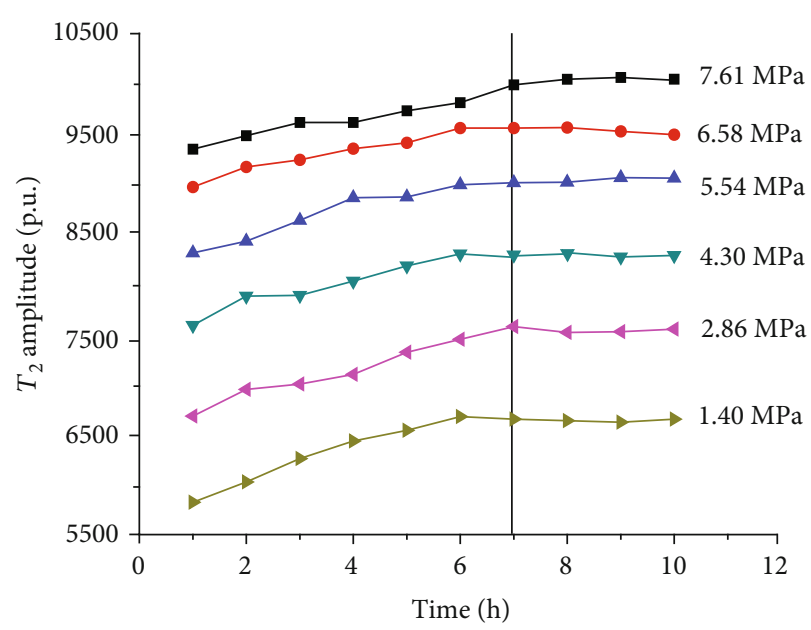

(b) ZCD

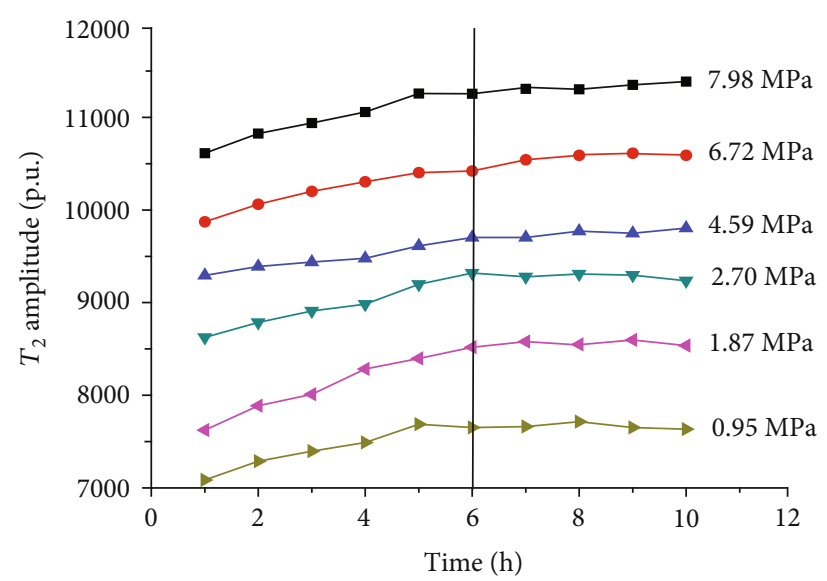

(d) XQ

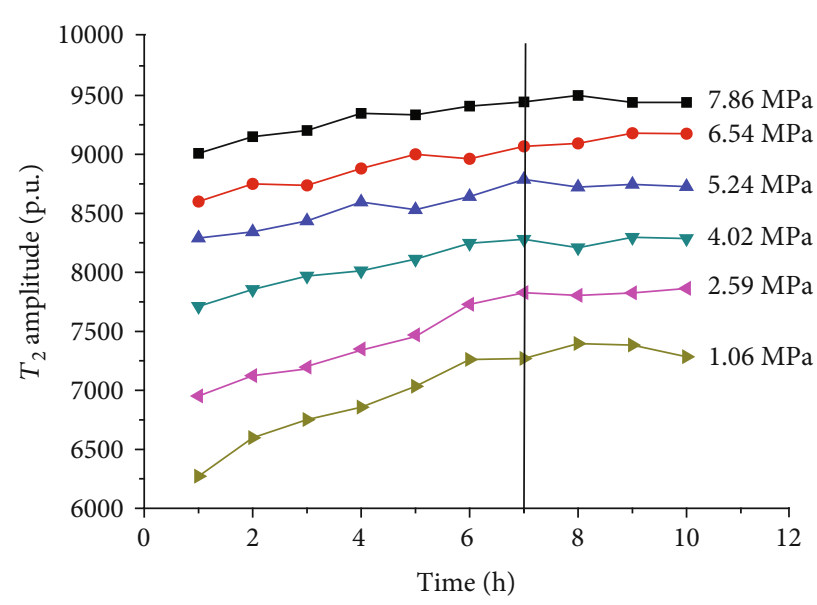

(f) DEP

Figure 8: Continued. 


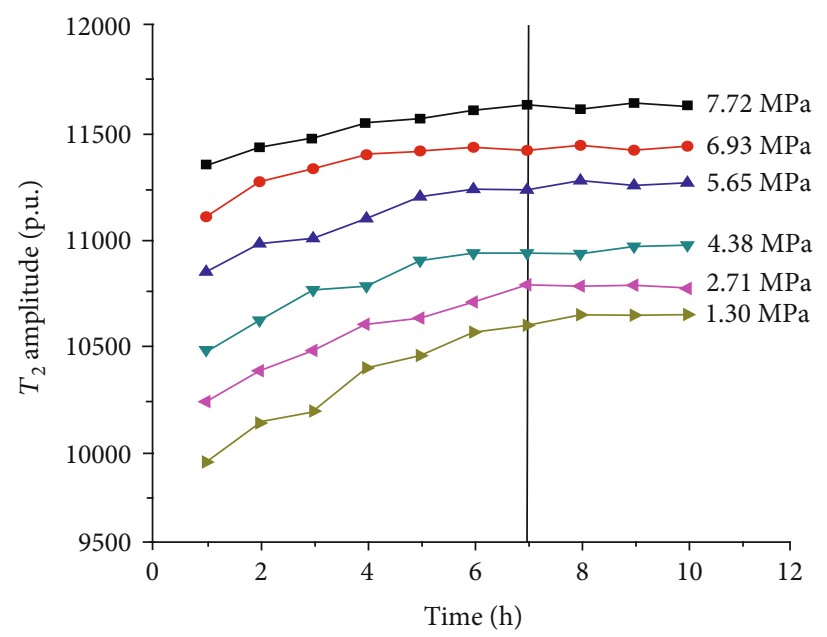

(g) DQ

FIGURE 8: Integrated amplitudes of adsorbed methane versus time after methane addition under the experimental pressures, ranging from 0 to $8 \mathrm{MPa}$.

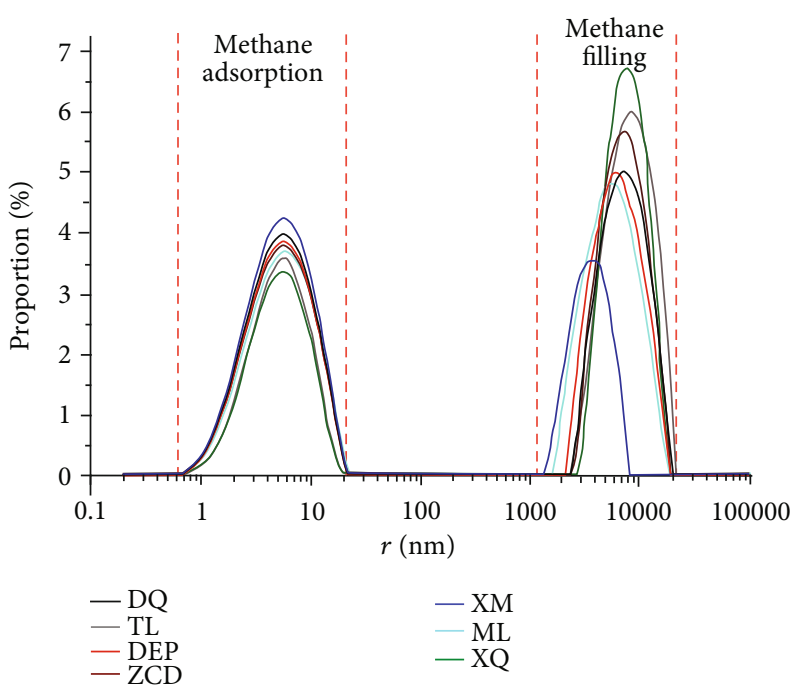

(a)

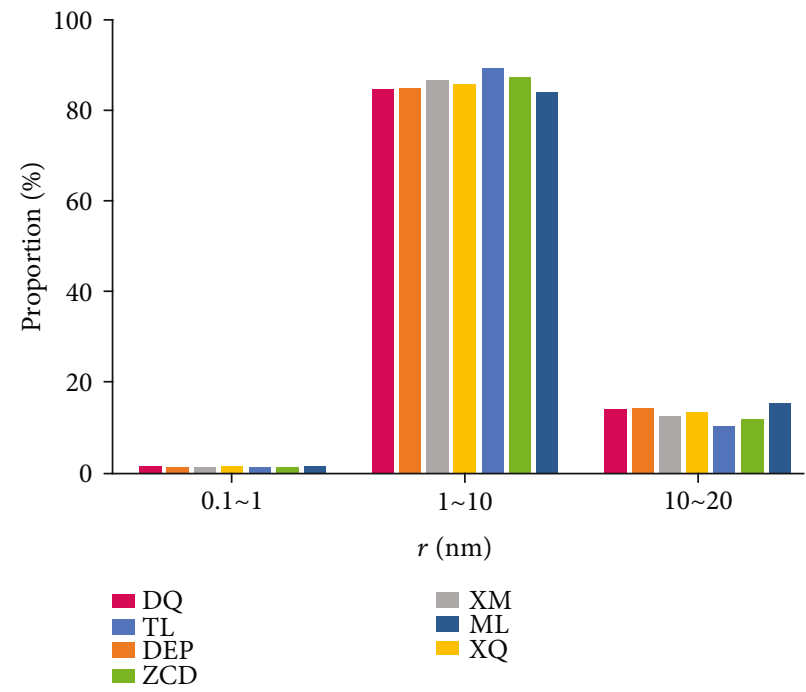

(b)

Figure 9: The pore size distribution of selected coal samples after methane adsorption (a) and the proportion of adsorbed pore (b).

mainly distributed in two ranges $(0.5-20 \mathrm{~nm}$ and 1000 $20000 \mathrm{~nm})$. The relaxation in pore size range of $1000-$ $20000 \mathrm{~nm}$ represents the signal of free gas (i.e., free gas in the intergranular pore or void space), while the signal of adsorption gas exists in pore size range of $0.5-20 \mathrm{~nm}$. The main adsorption spaces of seven samples are all in the range of $1-10 \mathrm{~nm}$ (Figure 9 (b)). The $10-20 \mathrm{~nm}$ pore space contributes less than $20 \%$ to methane adsorption. The pore size in the range of $0.1 \sim 1 \mathrm{~nm}$ only slightly affected the methane adsorption property.

4.4. Influence of Coal Rank on Adsorption by the Modified Low-Field NMR Method. Methane adsorption capacity was affected by multiple factors, e.g., coal rank, maceral composition, and physical and chemical structure. As shown in Figure 10(a), the methane adsorption capacity rose while the coal rank of the sample increased as generally accepted.

Comparison of the results of adsorption experiments (modified low-field NMR method and volumetric method) shows that the absolute deviations and relative deviations become smaller while the $R_{\mathrm{o}}$ increases (Figures 10(b) and $10(\mathrm{c}))$. In the range of $R_{\mathrm{o}}$ from $1.08 \%$ to $1.80 \%$, the modified low-field NMR method shows a strong selective suitability on relative higher rank coal. Therefore, further work will need to explain the suitability of the low-field NMR method on other coal ranks. 


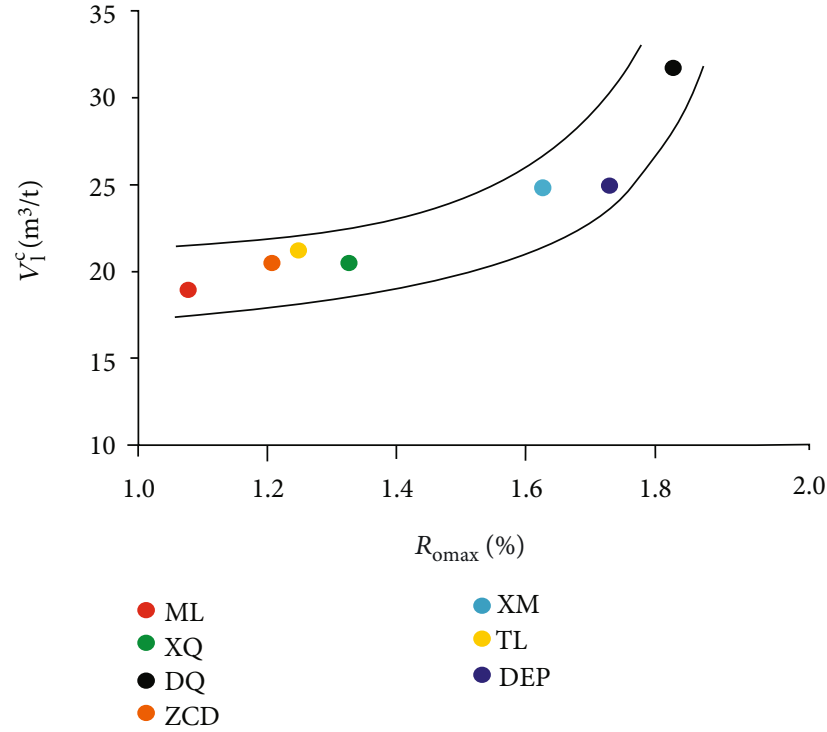

(a)

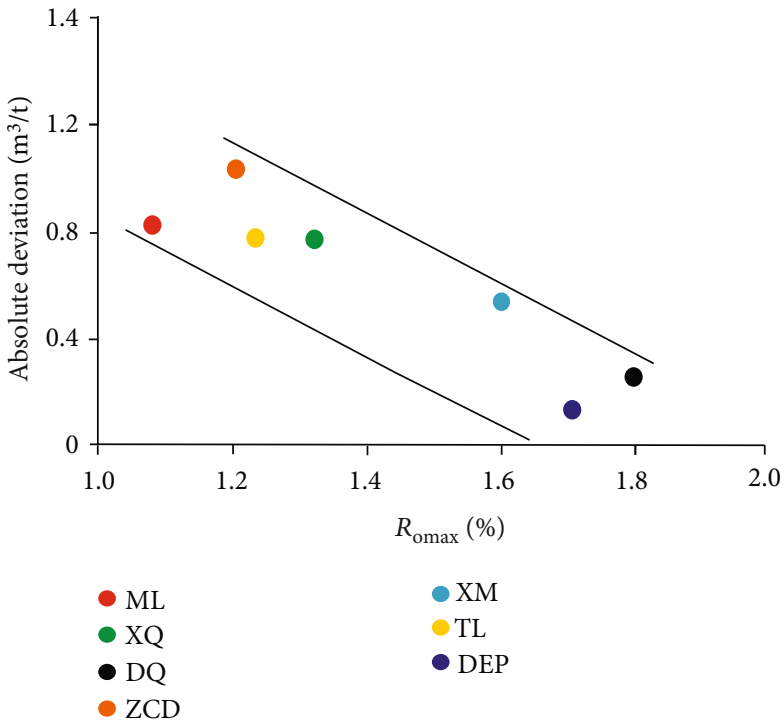

(b)

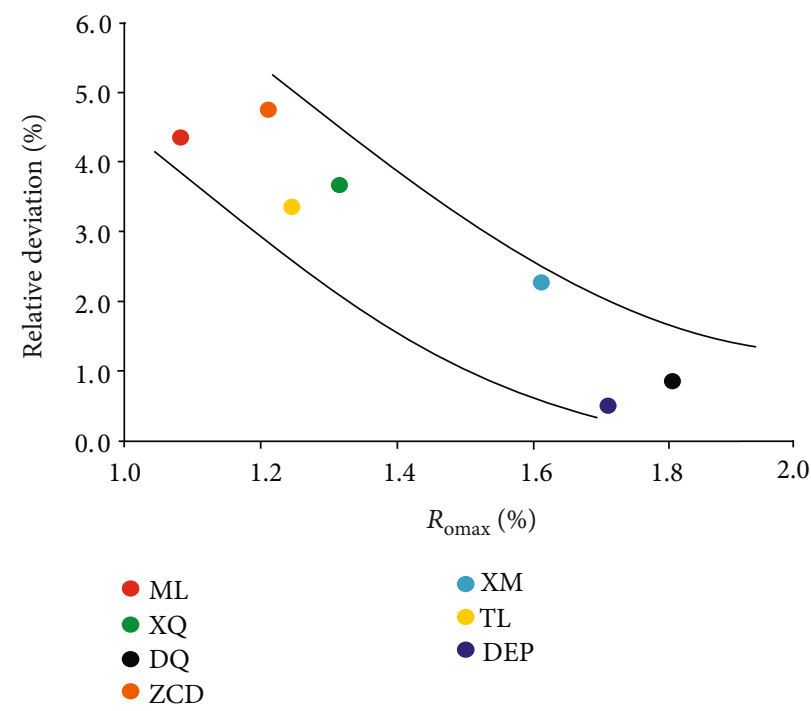

(c)

Figure 10: Relationship of (a) $R_{\mathrm{o}}$ vs. $V_{\mathrm{L}}{ }^{\mathrm{c}}$, (b) absolute deviations of $V_{\mathrm{L}}$ vs. $R_{\mathrm{o}}$, and (c) between the absolute deviations of $V_{\mathrm{L}}$ vs. $R_{\mathrm{o}}$.

\section{Conclusion}

Based on the experimental data of the low-field NMR and volumetric method, this paper analyzed the suitability of the modified low-field NMR method in coal. The nuclear magnetic $T_{2}$ relaxation spectra of coal samples have bimodal structure characteristic. The first peak represents adsorbed methane corresponding to $T_{2}<1 \mathrm{~ms}$, and the second peak characterizes bulk methane with ranges from $75 \mathrm{~ms}$ to $1000 \mathrm{~ms}$. The pore size in the range of $1-10 \mathrm{~nm}$ is the main contributor for gas adsorption in medium-rank coals. During the dynamic adsorption process, the $T_{2}$ amplitude increases rapidly during the first four hours and then increases slowly in the following two or three hours until the sample enters an equilibrium condition. The modified NMR method pro- duced a relatively lower deviation from the volumetric method compared with Yao et al.'s method (2014). The results of modified low-field NMR agrees well with those of the traditional volumetric method that absolute deviations do not exceed $1.03 \mathrm{~m}^{3} / \mathrm{t}$ while relative deviations are $<4.76 \%$. The deviations between the NMR and volumetric method decreased with $R_{\mathrm{o}}$ from $1.08 \%$ to $1.80 \%$ indicating that the modified low-field NMR method shows a strong selective suitability on relatively higher rank coals in this maturity range.

\section{Data Availability}

All data are derived from our experimental results, which can be provided in the appendix of the paper if necessary. 


\section{Conflicts of Interest}

The authors declare that they have no conflicts of interest.

\section{Acknowledgments}

This research was funded by the National Natural Science Foundation of China (41973077, 41902178, and U1910204); the Natural Science Foundation of Shanxi Province, China (201701D221026, 20181101013); and the Open Fund of Beijing Key Laboratory of Unconventional Natural Gas Geological Evaluation and Development Engineering, China University of Geosciences (Beijing) (2019BJ02001).

\section{References}

[1] Y. Li, D. Tang, D. Elsworth, and H. Xu, "Characterization of coalbed methane reservoirs at multiple length scales: a crosssection from southeastern Ordos Basin, China," Energy \& Fuels, vol. 28, no. 9, pp. 5587-5595, 2014.

[2] S. Yu, Z. Yan-ming, and L. Wu, "Macromolecule simulation and $\mathrm{CH}_{4}$ adsorption mechanism of coal vitrinite," Applied Surface Science, vol. 396, pp. 291-302, 2017.

[3] P. J. Crosdale, B. B. Beamish, and M. Valix, "Coalbed methane sorption related to coal composition," International Journal of Coal Geology, vol. 35, no. 1-4, pp. 147-158, 1998.

[4] M. D. Donohue and G. L. Aranovich, "Adsorption hysteresis in porous solids," Journal of Colloid and Interface Science, vol. 205, no. 1, pp. 121-130, 1998.

[5] J. Rouquerol, D. Avnir, C. W. Fairbridge et al., "Recommendations for the characterization of porous solids (technical report)," Pure and Applied Chemistry, vol. 66, no. 8, pp. 1739-1758, 1994.

[6] G. Gaus, A. Kalmykov, B. M. Krooss, and R. Fink, "Experimental investigation of the dependence of accessible porosity and methane sorption capacity of Carbonaceous shales on particle size," Geofluids, vol. 2020, Article ID 2382153, 13 pages, 2020.

[7] P. J. Crosdale, T. A. Moore, and T. E. Mares, "Influence of moisture content and temperature on methane adsorption isotherm analysis for coals from a low-rank, biogenically-sourced gas reservoir," International Journal of Coal Geology, vol. 76, no. 1-2, pp. 166-174, 2008.

[8] A. Hildenbrand, B. M. Krooss, A. Busch, and R. Gaschnitz, "Evolution of methane sorption capacity of coal seams as a function of burial history - a case study from the Campine Basin, NE Belgium," International Journal of Coal Geology, vol. 66, no. 3, pp. 179-203, 2006.

[9] C. Laxminarayana and P. J. Crosdale, "Role of coal type and rank on methane sorption characteristics of Bowen Basin, Australia coals," International Journal of Coal Geology, vol. 40, no. 4, pp. 309-325, 1999.

[10] C. Laxminarayana and P. J. Crosdale, "Controls on methane sorption capacity of Indian coals," Bulletin, vol. 86, no. 2, pp. 201-212, 2002.

[11] A. Olajossy, "The influences of the rank of coal on methane sorption capacity in coals/Wpływ Rzędu Węgla Na Pojemność Sorpcyjną Metanu W Węglach," Archives of Mining Sciences, vol. 59, no. 2, pp. 509-516, 2014.

[12] T. C. Ruppel, C. T. Grein, and D. Bienstock, "Adsorption of methane on dry coal at elevated pressure," Fuel, vol. 53, no. 3, pp. 152-162, 1974.
[13] B. Ryan and T. Gentzis, "Controls on methane adsorption capacity of lower Cretaceous coals from northeastern British Columbia, Canada: part 2-effect of temperature, pressure, maceral composition, and mineral matter on adsorption," Energy Sources, vol. 25, no. 12, pp. 1155-1170, 2003.

[14] E. Yalçin and Ş. Durucan, "Methane capacities of Zonguldak coals and the factors affecting methane adsorption," Mining Science and Technology, vol. 13, no. 2, pp. 215-222, 1991.

[15] Q. L. Zhang, "Adsorption mechanism of different coal ranks under variable temperature and pressure conditions," Journal of China University of Mining and Technology, vol. 18, no. 3, pp. 395-400, 2008.

[16] L. Zhang, N. Aziz, T. Ren, S. Tu, and J. Nemcik, "Influence of coal particle size on coal adsorption and desorption characteristics," Archives of Mining Sciences, vol. 59, no. 3, pp. 807-820, 2014.

[17] L. Brochard, M. Vandamme, J. M. Pellenq, and T. Fen-Chong, "Adsorption-induced deformation of microporous materials: coal swelling induced by $\mathrm{CO}_{2}-\mathrm{CH}_{4}$ competitive adsorption," Langmuir, vol. 28, no. 5, pp. 2659-2670, 2012.

[18] S. Y. Liu, B. J. Sun, J. C. Xu, H. Li, and X. Wang, "Study on competitive adsorption and displacing properties of $\mathrm{CO}_{2}$ enhanced shale gas recovery: advances and challenges," Geofluids, vol. 2020, Article ID 6657995, 15 pages, 2020.

[19] J. Liu, L. Z. Xie, D. Elsworth, and Q. Gan, " $\mathrm{CO}_{2} / \mathrm{CH}_{4}$ competitive adsorption in shale: implications for enhancement in gas production and reduction in carbon emissions," Environmental Science \& Technology, vol. 53, no. 15, pp. 9328-9336, 2019.

[20] J. Liu, L. Z. Xie, B. He, Q. Gan, and P. Zhao, "Influence of anisotropic and heterogeneous permeability coupled with insitu stress on $\mathrm{CO}_{2}$ sequestration with simultaneous enhanced gas recovery in shale: quantitative modeling and case study," International Journal of Greenhouse Gas Control, vol. 104, article 103208, 2021.

[21] H. G. Sui and J. Yao, "Molecular simulation of $\mathrm{CO}_{2} / \mathrm{CH}_{4}$ competitive adsorption in kerogen," Journal of China University of Petroleum, vol. 40, no. 2, pp. 147-154, 2016.

[22] W. N. Zhou, H. B. Wang, Z. Zhang, H. Chen, and X. Liu, "Molecular simulation of $\mathrm{CO} 2 / \mathrm{CH} 4 / \mathrm{H} 2 \mathrm{O}$ competitive adsorption and diffusion in brown coal," RSC Advances, vol. 9, no. 6, pp. 3004-3011, 2019.

[23] A. Busch and Y. Gensterblum, "CBM and CO2-ECBM related sorption processes in coal: a review," International Journal of Coal Geology, vol. 87, no. 2, pp. 49-71, 2011.

[24] J. E. Fitzgerald, Z. Pan, M. Sudibandriyo, K. A. M. Gasem, S. Reeves, and R. L. Robinson, Jr, "Adsorption of methane, nitrogen, carbon dioxide and their mixtures on wet Tiffany coal," Fuel, vol. 84, no. 18, pp. 2351-2363, 2005.

[25] B. M. Krooss, F. van Bergen, Y. Gensterblum, N. Siemons, H. J. M. Pagnier, and P. David, "High-pressure methane and carbon dioxide adsorption on dry and moisture-equilibrated Pennsylvanian coals," International Journal of Coal Geology, vol. 51, no. 2, pp. 69-92, 2002.

[26] J. Luo, Y. Liu, C. Jiang, W. Jie, H. Xie, and W. Chu, "Experimental and modeling study of methane adsorption on activated carbon derived from anthracite," Journal of Chemical \& Engineering Data, vol. 56, no. 12, pp. 4919-4926, 2011.

[27] S. Reeves, R. Gonzalez, K. A. Gasem et al., "Measurement and prediction of single and multi-component methane, carbon dioxide and nitrogen isotherms for U.S. coals," International Coalbed Methane Symposium, vol. 527, pp. 16-20, 2005. 
[28] N. Siemons, K. H. A. A. Wolf, and J. Bruining, "Interpretation of carbon dioxide diffusion behavior in coals," International Journal of Coal Geology, vol. 72, no. 3-4, pp. 315-324, 2007.

[29] R. Wang, N. S. Zhang, X. J. Liu, X. Wu, J. Chen, and L. Ma, "Characteristics of pore volume distribution and methane adsorption on shales," Adsorption Science \& Technology, vol. 33, no. 10, pp. 915-937, 2015.

[30] J. S. Bae and S. K. Bhatia, "High-pressure adsorption of methane and carbon dioxide on coal," Energy \& Fuels, vol. 20, no. 6, pp. 2599-2607, 2006.

[31] M. J. Chen, Y. L. Kang, T. S. Zhang, X. Li, K. Wu, and Z. Chen, "Methane adsorption behavior on shale matrix at in-situ pressure and temperature conditions: measurement and modeling," Fuel, vol. 228, pp. 39-49, 2018.

[32] R. Sakurovs, S. Day, and S. Weir, "Relationships between the sorption behaviour of methane, carbon dioxide, nitrogen and ethane on coals," Fuel, vol. 97, pp. 725-729, 2012.

[33] Y. Gensterblum, A. Merkel, A. Busch, and B. M. Krooss, "High-pressure $\mathrm{CH}_{4}$ and $\mathrm{CO}_{2}$ sorption isotherms as a function of coal maturity and the influence of moisture," International Journal of Coal Geology, vol. 118, pp. 45-57, 2013.

[34] S. Harpalani, B. K. P. Prusty, and P. Dutta, "Methane/ $\mathrm{CO}_{2}$ sorption modeling for coalbed methane production and $\mathrm{CO}_{2}$ sequestration," Energy and Fuels, vol. 20, no. 4, pp. 15911599, 2006.

[35] D. Y. Li, Q. F. Liu, P. Weniger, Y. Gensterblum, A. Busch, and B. M. Krooss, "High-pressure sorption isotherms and sorption kinetics of $\mathrm{CH}_{4}$ and $\mathrm{CO}_{2}$ on coals," Fuel, vol. 89, no. 3, pp. 569$580,2010$.

[36] X. S. Bin, Y. Y. Bin, C. J. Yu, and W. Yao, "Research of micropore structure in coal reservoir using low-field NMR," Journal of China Coal Society, vol. 40, pp. 170-176, 2015.

[37] Y. D. Cai, D. M. Liu, Z. J. Pan, Y. Yao, J. Li, and Y. Qiu, "Petrophysical characterization of Chinese coal cores with heat treatment by nuclear magnetic resonance," Fuel, vol. 108, pp. 292-302, 2013.

[38] Q. Q. He, Y. J. Cao, Z. Y. Miao, X. Ren, and J. Chen, "Estimation of pores distribution in lignite utilizing $\mathrm{Hg}, \mathrm{H}_{2} \mathrm{O}, \mathrm{CO}_{2}$, and $\mathrm{N}_{2}$ as molecular probes," Energy \& Fuels, vol. 31, no. 12, pp. 13259-13265, 2017.

[39] Z. S. Liu, D. M. Liu, Y. D. Cai, and Z. Pan, “The impacts of flow velocity on permeability and porosity of coals by core flooding and nuclear magnetic resonance: implications for coalbed methane production," Journal of Petroleum Science and Engineering, vol. 171, pp. 938-950, 2018.

[40] X. F. Ji, D. Y. Song, H. T. Zhao, Y. Li, and K. He, "Experimental analysis of pore and permeability characteristics of coal by low-field NMR," Applied Sciences, vol. 8, no. 8, 2018.

[41] X. X. Sun, Y. B. Yao, D. M. Liu, and Y. Zhou, "Investigations of $\mathrm{CO}_{2}$-water wettability of coal: NMR relaxation method," International Journal of Coal Geology, vol. 188, pp. 38-50, 2018.

[42] Z. Q. Tang, S. Q. Yang, C. Zhai, and Q. Xu, "Coal pores and fracture development during CBM drainage: their promoting effects on the propensity for coal and gas outbursts," Journal of Natural Gas Science and Engineering, vol. 51, pp. 9-17, 2018.

[43] S. B. Xie, The application of low-field nuclear magnetic resonance (NMR) in the analysis of physical properties and adsorption ability of coal reservoirs (Master's dissertation), 2015.

[44] D. J. Xue, H. W. Zhou, Y. T. Liu, L. Zhang, and L. S. Deng, "Study of drainage and percolation of nitrogen-water flooding in tight coal by NMR imaging," Rock Mechanics and Rock Engineering, vol. 51, no. 11, pp. 3421-3437, 2018.

[45] Y. B. Yao, D. M. Liu, Y. Che, D. Tang, S. Tang, and W. Huang, "Petrophysical characterization of coals by low-field nuclear magnetic resonance (NMR)," Fuel, vol. 89, no. 7, pp. 1371$1380,2010$.

[46] G. L. Zhang, P. G. Ranjith, M. S. Perera, A. Haque, X. Choi, and K. S. M. Sampath, "Characterization of coal porosity and permeability evolution by demineralisation using image processing techniques: a micro-computed tomography study," Journal of Natural Gas Science and Engineering, vol. 56, pp. 384-396, 2018.

[47] S. J. Zheng, Y. B. Yao, D. M. Liu, Y. Cai, Y. Liu, and X. Li, "Nuclear magnetic resonance $T_{2}$ cutoffs of coals: a novel method by multifractal analysis theory," Fuel, vol. 241, pp. 715-724, 2019.

[48] R. Guo, K. Mannhardt, and A. Kantzas, "Characterizing moisture and gas content of coal by low-field NMR," Journal of Canadian Petroleum Technology, vol. 46, no. 10, pp. 49-54, 2007.

[49] Y. B. Yao, D. M. Liu, and S. B. Xie, "Quantitative characterization of methane adsorption on coal using a low-field NMR relaxation method," International Journal of Coal Geology, vol. 131, pp. 32-40, 2014.

[50] Y. B. Yao, J. Liu, D. M. Liu, J. Chen, and Z. Pan, "A new application of NMR in characterization of multiphase methane and adsorption capacity of shale," International Journal of Coal Geology, vol. 201, pp. 76-85, 2019.

[51] C. Morriss, D. Rossini, C. Straley et al., "Core analysis by lowfield NMR,” The Log Analyst, vol. 38, no. 2, 1997.

[52] G. R. Coates, L. Xiao, and M. G. Prammer, NMR logging: principles and applications, vol. 234, Haliburton Energy Services, Houston, 1999.

[53] C. Liu, P. Liu, and X. Zhang, "Study on determination points of vitrinite random reflectance for mixed coal in GB/T 69482008," Coal Quality Technology, vol. 2, pp. 20-21, 2011.

[54] K. Jin, Y. Cheng, Q. Liu et al., "Experimental investigation of pore structure damage in pulverized coal: implications for methane adsorption and diffusion characteristics," Energy \& Fuels, vol. 30, no. 12, pp. 10383-10395, 2016.

[55] A. Eberle, H. King, P. Ravikovitch, C. C. Walters, G. Rother, and D. J. Wesolowski, "Direct measure of the dense methane phase in gas shale organic porosity by neutron scattering," Energy \& Fuels, vol. 30, no. 11, pp. 9022-9027, 2016. 